\title{
World Petroleum Legislation: Frameworks That Foster OIL aNd Gas DEvelopment
}

\author{
William T. OnORato and J. Jay Park“
}

In this article the authors draw upon the experience of the World Bank in encouraging petroleum investment in its member countries to analyze the essential elements of international-standard legislative frameworks for petroleum exploration and production operations. The basic components of Petroleum Law, Regulations, and Model Contracts are examined with a view to explaining the principles and rationale for each essential element of successful legislative frameworks while recognizing that there is room for a myriad of variations and innovation depending on the hydrocarbon endowment, real or perceived, of each host government.
Dans cet article, les auteurs s'inspirent de l'expérience de la Banque mondiale à encourager les investissements pétroliers dans ses pays membres pour analyser les éléments essentiels d'un cadre législatif à norme internationale régissant les activités d'exploration et de production pétrolières. Les principes de base de la loi, de la réglementation et des contrats types relatifs au pétrole y sont étudiés en vue d'expliquer les principes et le raisonnement de chaque élément essentiel d'un cadre législatif à succès tout en reconnaissant qu'il faut laisser place à une myriade de variations eld'innovations selon la richesse en hydrocarbures, réelle ou perçue, de chaque gouvernement hôte.

\section{TABle of CONTENTS}

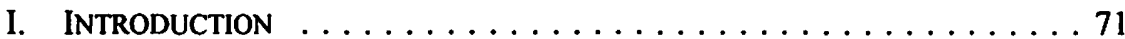

II. EsSENTIAL Elements of A PETROLEUM LAW . . . . . . . . . 73

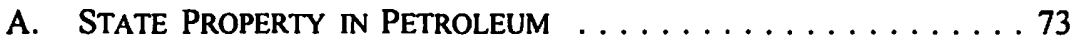

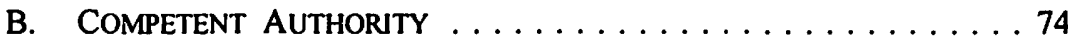

C. PEtroleum OPERATIONS $\ldots \ldots \ldots \ldots \ldots \ldots \ldots \ldots \ldots \ldots$

D. PETROleum AgREEMENTS $\ldots \ldots \ldots \ldots \ldots \ldots \ldots$

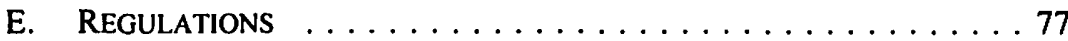

F. QUALIFICATIONS, DUTIES, AND RIGHTS OF

RIGHTS HOLDER OR CONTRACTOR ............ 78

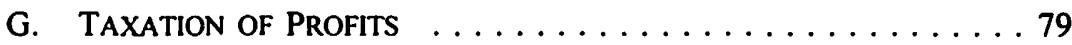

H. Other TAXes, Duties, and Exchange Controls $\ldots \ldots \ldots 81$

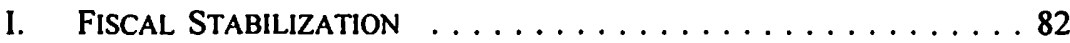

J. Environmental PRotection AND SAfETy . . . . . . . 83

K. Miscellaneous Provisions . . . . . . . . . . . . . . . 84

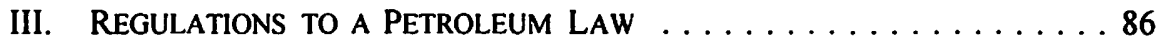

A. COMPETENT AUTHORITY .............. 86

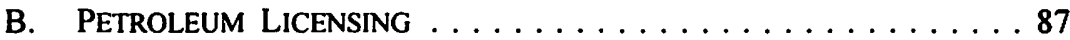

C. PETROLEUM OPERATIONS ................. 89

D. Petroleum AgreEMENTS . . . . . . . . . . . . . 90

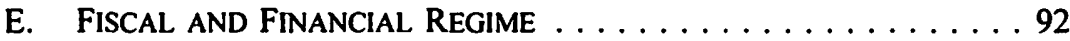

F. ASSIGNMENT OF RIGHTS . . . . . . . . . . . . . . 94

G. LAND USE . . . . . . . . . . . . . . . . 95

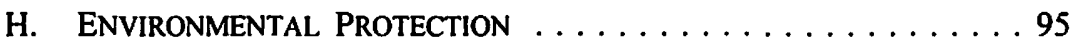

I. MiscEllaneOUS Provisions ................ 96

B.A., J.D. Ph.D. (Cantab); Legal Adviser, Energy \& Mining Legal Department, World Bank Group, Washington, D.C.; Adjunct Professor of Law, Georgetown University Law Center.

• $\quad$ LL.B. (Osgoode Hall Law School); Partner, Macleod Dixon, Calgary, Alberta. 
J. MODEL FORMS ..................... 97

IV. MODEL CONTRACT $\ldots \ldots \ldots \ldots \ldots \ldots \ldots$

A. SCOPE, DURATION, AND GRANT OF RIGHTS . . . . . . . . . . . . 99

B. MWO, Work Program, and GuaranteEs . . . . . . . . 100

C. RELINQUISHMENTS ... . . . . . . . . . . . . . . . 100

D. DECLARATION OF COMMERCIAL DISCOVERY . . . . . . . . . . 100

E. JoINT MANAGEMENT [AdVisory] COMMITTEE . . . . . . . . . 101

F. COST RECOVERY, EXPENSES, AND PRODUCTION SHARES ................. 101

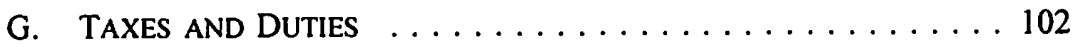

H. FEES AND BONUSES ................ 103

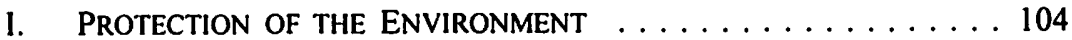

J. SUPPLY OF DOMESTIC MARKET;

EMERGENCY REQUISITION . . . . . . . . . . . . . . . . . . . . 104

K. TRAINING OF HOST GovernMENT PERSONNEL . . . . . . 105

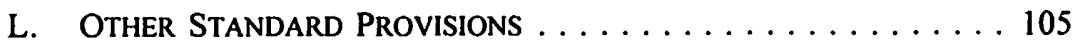

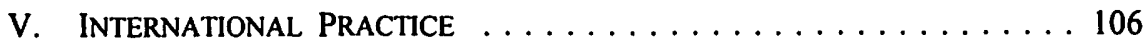
A. THE VALUE OF KNOWING

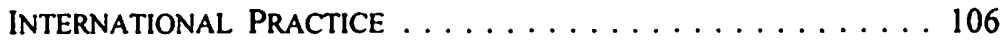
B. INTERNATIONAL PRACTICE REVIEW . . . . . . . . . . . . 106
C. SElected International Practice

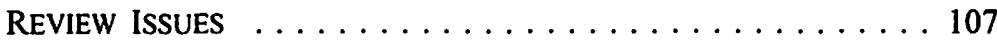

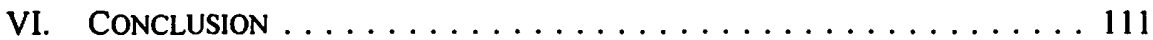

\section{INTRODUCTION}

It is the mandate of the World Bank to assist in the elimination of poverty in developing countries around the world. Most people are familiar with the World Bank's role in providing loan assistance to its member countries, and this remains a major part of the activities of the Bank and its related agencies. However, another role that the World Bank has played is to support the development of enabling legislation which would assist World Bank members with petroleum potential in attracting foreign direct investment and risk capital into this critical sector of their economies. This is typically done through active participation in the legal reform and technical assistance ("TA") components of Petroleum Exploration Promotion Projects.

The objectives of these technical assistance programs is to aid in the development of acceptable, international-standard, legal, contractual, and fiscal frameworks to encourage a quickening of the pace of petroleum investment operations in the territories of member countries. Thus, since 1980, the World Bank has financed Petroleum Exploration Promotion Projects and other forms of petroleum sector legal reform and TA with the consistent objective of acting as a "catalyst" to mobilize the inflow of foreign direct 
investment ${ }^{1}$ into the developing petroleum sectors of more than forty member countries worldwide. $^{2}$

\begin{tabular}{|l|}
\hline I. Foreign Invesiment \\
From a Host Country Perspective \\
\hline The importance of foreign investment in the petroleum sector: \\
-To increase petroleum resources development and reserves \\
-To increase access to modern technology \\
-To improve management skills and profit orientation \\
-To increase financial resources for development \\
-To establish long-term relationships with international oil companies \\
-To establish long-term relationship with the global oil and gas market
\end{tabular}

In view of this extensive experience in advising on the drafting of internationalstandard legal, contractual, and fiscal frameworks for petroleum exploration and production ("E\&P") operations in host countries, this article seeks to draw together, discuss, and critique the essential elements of such frameworks, and to provide the authors' recommendations on how best to structure these elements for the maximum attainment of their intended goals. While this article clarifies and explains the principles and rationale for each essential element of such successful legislative frameworks, it must be emphasized that the circumstances applicable in each country are often unique. For this reason, in part, this article concentrates exclusively on providing an explanation of principles and elements of such model regimes, but pointedly offers neither model language, clauses, nor codes for their drafting. ${ }^{3}$

Briefly, the main purposes of a legislative framework are to provide the basic context for, and the rules governing, petroleum operations in the host country; to regulate them as they are carried out by both domestic, foreign and international enterprises; and to define the principal administrative, economic, and fiscal guidelines for investment activity in the sector. This article identifies and details the essential elements of such a framework - the petroleum law ("Petroleum Law"), the regulations ("Regulations") and the model contract ("Model Contract") - and explains how these three components interrelate. Experience shows that the cornerstone of effective petroleum legislative frameworks for E\&P operations is a short but thorough, broad, and generic Petroleum Law complemented

I Pursuant to the Guidelines for Petroleum Lending, World Bank, 28 November 1984, OMS 3.82, Section III, para. 15.

$2 \quad$ Principally in Sub-Saharan Africa, Eastern Europe, Latin America and the Caribbean, and several Asian countries. In this regard, please see the Annex to this article detailing the World Bank group's petroleum sector loans, credits, investments, and legal TA activities since 1980.

1 It should also be stressed that the findings, interpretations, and conclusions expressed in this article are entirely those of the authors and should not be attributed to the World Bank, its Board of Directors, its management, or any of its member countries. 
by enabling Regulations and one or several variants of a Model Contract. Such frameworks provide both host governments and international oil company ("IOC") investors with a clear legal and contractual context within which to negotiate E\&P arrangements which are both mutually advantageous and which also facilitate development of the petroleum resources of the host government. In addition to the Petroleum Law, Regulations, and Model Contract(s), the fiscal and tax aspects of a complete petroleum legislative framework may either be detailed in the Petroleum Law itself or separately set out in a companion petroleum revenue code ("Petroleum Revenue Code"), either of which would complete the legislative package.

The core rationale behind the preference for a brief but thorough Petroleum Law is that it is meant to cover all essential concepts necessary to a modern, enabling Petroleum Law while not "setting them in stone" through unnecessary detail. In this legislative scheme, such detail is reserved for subsidiary instruments such as the Regulations and the Model Contract, which should not be required to be submitted to the legislature for amendment or change.

In addition, the best approach whenever possible is to package the legal, contractual, and fiscal regime for petroleum operations into a self-contained, coherent legislative framework. That framework should then be consistent with both the overall legal system of the host government, and with any applicable principles of international law. Such consistency is a great incentive to attracting significant foreign investment into the sector: Where an IOC is studying potential E\&P investments in candidate countries, given relatively equal petroleum-prospectivity, it will normally opt for the state which has such a coherent regime in place. The regime will be preferred to "piecing together" the legislative framework from provisions in both the Petroleum Law and other necessarily related and relevant laws, such as those on foreign investment, taxation, land use, and the environment.

\section{EsSential Elements of a Petroleum law}

The essential elements of a recommended Petroleum Law format include express provisions which address all of the following areas.

\section{A. State Property in Petroleum}

Through this provision the State asserts and confirms that all petroleum (normally a defined term) lying within its jurisdiction, both onshore and offshore (including offshore areas where it exercises exclusive economic interest over such resources), is the exclusive property of the State. Any provisions to the contrary in other laws or rights granted or vested thereunder in derogation of this are expressly superseded by this provision in the Petroleum Law. This approach is consistent with applicable international standards and established practice on the topic. While there are a few significant exceptions to this general practice ${ }^{4}$ (for example, where land tenure systems are predominantly biased

Notably found in the United States, excluding state lands, federal lands, the continental shelf under state jurisdiction and the outer continental shelf under federal jurisdiction. In fact, despite private land ownership as a system, the State is by far the largest owner of land in the United States. 
toward private sector ownership, including private ownership of subsurface mineral rights unsevered from the entire land parcel), these exceptions are a marked minority view which evolving international practice on the question has not chosen to assimilate or replicate. In any event, the rationale behind the preferred legislative framework is predicated on the fact that the State exclusively owns its petroleum resources.

\section{Host Country's Objectives}

Host Country's Objectives for Petroleum Development

Economic Agenda:

- To develop the sector

- To gain access to its petroleum resources

- To generate revenues from taxes and "take"

- To obtain technology transfer

- To obtain "know-how"

Political and Social Agenda:

- To stimulate competition in the sector

- To encourage or pressure its National Oil Company to reform

- To preserve political and strategic alliances

- To liberalize sector prices
- To retain most of its petroleum wealth

- To create employment

- To generate and retain hard currency

- To foster social prerequisites

\section{B. COMPETENT AUTHORITY}

The Petroleum Law should clearly identify a single government agency, or competent authority ("Competent Authority"), vested with the exclusive mandate to implement government policy in the area of petroleum development. The Competent Authority represents the State in negotiating and contracting with foreign investors and in regulating and administering, from both a policy and technical compliance viewpoint, the implementation of contracts once they have been signed. Ideally, the Competent Authority should be named in the Petroleum Law, so that potential investors will know what will be their single point of contact with the government. ${ }^{5}$ Preferably, that Competent Authority should be a ministry or other body having considerable sectoral expertise and experience. In most countries this role is fulfilled by the local equivalent of a ministry of energy or petroleum as this body usually has responsibility for petroleum exploration, development, and production. 
Often, however, the state of petroleum development in a given host country will produce variants of this basic approach. This is particularly true at the extreme ends of the scale where the host country is either a developed petroleum province, or a neophyte to the sector. In the former case, it is likely that the State has already created a national oil company ("NOC") which possesses varying degrees of experience and responsibilities. In addition, the State may also have vested the NOC with exclusive authority over the sector as the de facto Competent Authority, allowing it to fulfill specific functions such as: allocating acreage by direct negotiation or tender, while itself retaining or competing for such acreage; contracting on behalf of the State with the selected licensees or participating as State partner in joint ventures; and administering the petroleum contract and acting as technical interface for the State with the licensee. ${ }^{6}$ The fulfillment of these functions together by a NOC is not recommended. Rather, a separate Competent Authority should hold the State's patrimony in its petroleum resources, conduct competitive bidding and/or direct negotiations, and ultimately issue licences to successful bidders. The Competent Authority should contract on behalf of the State, not on behalf of the NOC. The NOC should not have the authority to either allocate acreage to potential licensees, or to compete for acreage itself, as this would be a strong disincentive to foreign investment. Assuming, however, that the Competent Authority, within or adjunct to the applicable ministry, was the licensing authority for the State, the NOC could be left to act as contract administrator and technical interface, carrying out the State's technical functions within the sector, but not its sovereign, regulatory, and commercial functions. ${ }^{7}$

Where the State in question is completely new to the petroleum sector, it is often the case that there is no central ministry with either responsibility for, or expertise in, petroleum operations; nor would there be a NOC. More likely, petroleum, if addressed at all in a legal context, would be included in an outdated minerals or mining law. Thus, aside from the need for a modern legislative framework for petroleum development, there will be the need to create a Competent Authority with adequate expertise and authority. This will require institutional strengthening and consensus. Rather than a competition between interested ministries (e.g., geology, environment, commerce and trade, finance) it is often expedient in such case, as an interim solution, to establish the Competent Authority as an inter-ministerial council or consultative group which has the full authority to license, contract, and supervise petroleum operations. ${ }^{8}$ Concurrently, expertise can be

6 As was historically the case, for example, in India, with ONGC; in Romania, with PETROM; in Azerbaijan, with SOCAR; and in Vietnam, with PetroVietnam. In each case, World Bank legal TA included or will include components to restructure or realign the institutional infrastructure of the sector to move it away from such exclusive authority for the relevant NOCs.

Which, in turn, sometimes raises the difficult question of State "participation" through its NOC. A carried percentage participation interest, however low, affects the fiscal package as an additional tax on exploration. At the development stage, the question will then arise as to how the NOC will raise the necessary financing to meet cash calls for its participation percentage. Thus significant State participation is often discouraged, limiting it to, at most, 10 percent for the purposes of technology transfer, training, acquisition of "know how," and a voice in operations for the State through its NOC.

- As was proposed by the Energy Sector Management Assistance Program ("ESMAP") to Polish authorities under a Petroleum Exploration Promotion Project conducted in parallel to Loan No. 3215 Petroleum Law. The ad hoc "Inter-Ministerial Commission" would be comprised of representatives of the ministries of industry, finance and environmental protection, natural resources and forestry, charged with full authority to consult, supervise, and award petroleum licences. 
developed through experience, training, and participation, ultimately leading to the creation of a true, separate Competent Authority with the requisite staff and mandate.

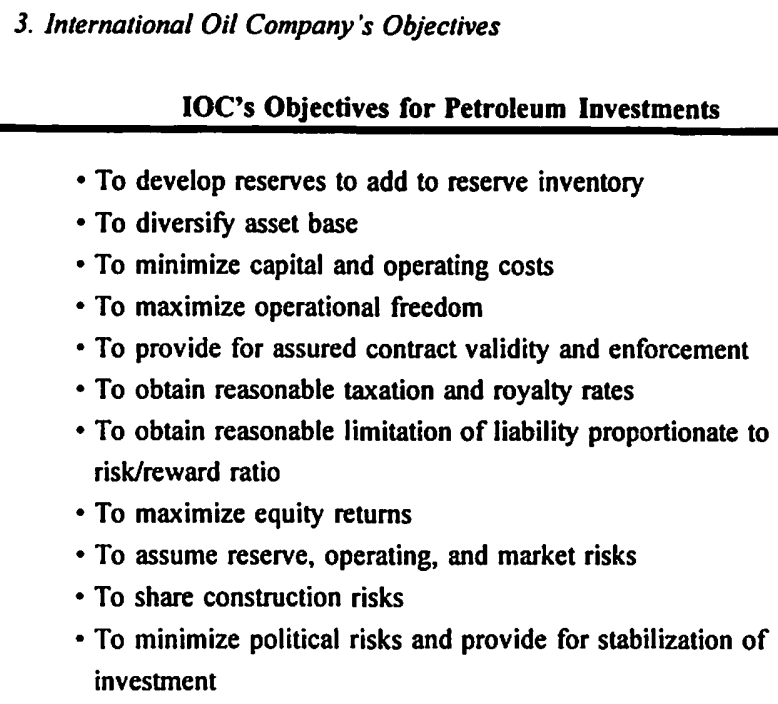

- To develop reserves to add to reserve inventory

- To diversify asset base

- To minimize capital and operating costs

- To maximize operational freedom

- To provide for assured contract validity and enforcement

- To obtain reasonable taxation and royalty rates

- To obtain reasonable limitation of liability proportionate to risk/reward ratio

- To maximize equity returns

- To assume reserve, operating, and market risks

- To share construction risks

- To minimize political risks and provide for stabilization of investment

\section{Petroleum OPERATIONS}

This essential provision has a dual purpose. First, it is meant to ensure that petroleum operations are conducted only under a permit or licence duly issued by the Competent Authority, in such form and on such terms as are prescribed in the Petroleum Law, the Regulations, and, where applicable, a petroleum agreement ("Petroleum Agreement"), the terms of which must be consistent with the enumerated requirements thereof in both the Petroleum Law and the Regulations. Second, it is intended to give the State the maximum possible flexibility as regards its means of conducting petroleum operations. This may be achieved through a State authority, such as an NOC; a private entity, such as an incorporated joint venture; or in any other manner which it may deem appropriate. This would all be within the bounds of established international norms and standards to attract foreign investment to a known and conducive setting in the sector.

\section{PETROLEUM AGREEMENTS}

Under this provision of the Petroleum Law, the concept and outline contents of a Model Contract is introduced. It authorizes the Competent Authority to have prepared and to make available Model Contracts to potential applicants as the State's starting point for the negotiation of an E\&P Petroleum Agreement. In some Petroleum Laws, a copy of a Model Contract is appended to the law as an exhibit. This would enact the Model Contract format as part of the Petroleum Law. However, it is much better not to follow this course. 
One must weigh the desirability of enacting a detailed and not easily changed or revised Model Contract with the force of law, against merely identifying its essential, minimum provisions in the Petroleum Law, thus establishing their legal basis. This leaves the full details and negotiable points to the Model Contract as a flexible instrument, subsidiary in position to the Petroleum Law. The latter course is recommended. The Petroleum Law should be couched in terms of the permissive minimal contents of a Model Contract (such as that detailed in Section IV below) without legislating its provisions in detail. This is the "generic" aspect of such a Petroleum Law, which provides only the necessary legal underpinnings and thereby leaves with the State a maximum number of negotiating options.

This section of the Petroleum Law will also consider the role of the Competent Authority in negotiating and concluding Petroleum Agreements; directly or indirectly supervising petroleum operations under Petroleum Agreements; revoking or suspending Petroleum Agreements for cause (after due notice to the rights holder and a reasonable period for it to effect cure); the granting of non-exclusive prospecting permits for the purpose of obtaining information on hydrocarbon endowment; and, depending on how the Petroleum Law is meant to interact with the State's mining law, if at all, the granting of mining permits for areas already subject to petroleum operations (as long as the former does not interfere with the latter).

\section{E. Regulations}

As considered above, Regulations should be subsidiary instruments to the Petroleum Law and should not themselves be enacted as law. Instead, this section of the Petroleum Law should expressly authorize the Competent Authority to make Regulations from time to time, consistent with the policy and objectives of the Petroleum Law. This provides the regime with flexibility allowing for changes to be made quickly in response to current developments, and without the need for a protracted and often non-expert legislative process. ${ }^{9}$ The safeguard is that the Regulations and any amendments thereto may never be inconsistent with the Petroleum Law.

For greatest clarity, the Petroleum Law should bring forward into its text for summary mention the general areas in which the Competent Authority may make Regulations. These will be dealt with in greater detail in Section III below. In addition, the Petroleum Law should also give the Competent Authority broad authority to make any other Regulations which it considers necessary in order to give effect to the provisions and policy objectives of the Petroleum Law.

9 While this is the preferred majority practice, a petroleum TA mission to Cyprus found that under its present Petroleum Law, Regulations are to be made by the Council of Ministers acting as the Competent Authority. In addition, the Petroleum Law provides that such Regulations will be enacted (or not opposed) by the Cypriot Parliament and, upon publication, become law. Thus the Regulations and the Petroleum Law together are law, rather than the desired flexible subsidiary instruments under the latter preferred practice. 


\section{F. QUalifications, Duties, AND Rights OF RIGHTS HOLDER OR CONTRACTOR}

First, it must be made clear in the Petroleum Law that Petroleum Agreements shall only be concluded with applicants who have the requisite financial resources, technical competence, and professional skills necessary to fulfill their obligations fully under such agreements. To this end the Competent Authority, as licensing authority, must have both the power and the duty to conduct "due diligence" inquiries on all applicants' qualifications, and to require them to provide satisfactory documentary evidence of those qualifications. This due diligence by the Competent Authority also serves to avert the undesirable result of awarding a licence or permit to a bidder that is not fully qualified and that has bid primarily in order to acquire rights to prospective acreage for the purpose of assigning or promoting it on at a profit, without undertaking any significant work program itself.

The principal duties of a rights holder under a Petroleum Agreement should be enumerated in the Petroleum Law and then amplified in greater detail in the Petroleum Agreement itself. In the Petroleum Law the rights holder's duties, to be specifically mentioned and replicated as terms in all Petroleum Agreements, include the following: reporting the discovery of any petroleum to the Competent Authority; presenting a development plan for commercial petroleum discoveries to the Competent Authority in a timely fashion, and promptly taking all reasonable steps to develop and produce the discovery; conducting all petroleum operations in accordance with good international petroleum industry practice, including measures to promote conservation, safety, and environmental protection; and indemnifying the Competent Authority against all claims made by third parties in respect of injury, damage, or loss caused by or resulting from any operations carried out by the rights holder or its subcontractors under a Petroleum Agreement.

In return, the rights holder under a Petroleum Agreement should be accorded certain guaranteed rights in the Petroleum Law, some of which are necessarily amplified in the Petroleum Agreement itself. The fundamental right is that the rights holder be granted the exclusive right to carry out petroleum operations within the area covered by the Petroleum Agreement, for the time period(s) specified therein, subject to the provisions of the Petroleum Agreement. As a corollary to the principle that an investor need only negotiate and conclude its arrangement with a single governmental authority, the Competent Authority, the total arrangement between the parties should be included in the Petroleum Agreement in contract form. Separate procedures involving further governmental discretion such as the granting of a licence or the conversion of a "prospecting or exploration licence" into a "production licence," as are prevalent in civil-law-based Petroleum Laws, are inadvisable unless they are mere formalities, the validity of which depends on the Petroleum Agreement. ${ }^{10}$ Thus any feasibility studies, expert evaluations, or requisite governmental approvals of a proposed arrangement should be obtained internally by the Competent Authority prior to signature of the Petroleum Agreement.

Ii' An example of this are the World Bank's comments to this effect - which were duly accepted to the draft Hydrocarbon Law of the Republic of the Congo. 
Allowing for the prevalence of civil code systems in certain areas, principally francophone Africa, the Middle East, Eastern Europe, and the republics of the former Soviet Union ("FSU"), the question of the precise legal nature of the licence or permit should be clarified in the Petroleum Law. In this regard, a clear divergence of views between IOCs and host governments exists. The former prefer that the licence be characterized and treated as a contract, thereby giving the State the ability to change the licence'sterms through subsequent legislation that is appropriately restrained. On the other hand, host governments tend to treat the licence as an administrative permit which will remain unchanged, except where made absolutely necessary by the dictates of public purpose. If changed, consideration must be given to the provision for adequate and just compensation of the affected licensee. This is especially true in civil code systems where the concept of the administrative contract is often applied to State licensing.

To reconcile these divergent views, the Petroleum Law should separately recognize the licence as a permit and the Petroleum Agreement as a contractual agreement. The terms and conditions of that contractual agreement must then be respected for the term of the contract and cannot be changed without the concurrence of both parties."

\section{G. Taxation of Profits}

As considered above, the tax and fiscal aspects of a complete petroleum E\&P legislative framework may either be detailed in the Petroleum Law itself, or set out separately in a companion Petroleum Revenue Code. The choice is often dictated by the depth and complexity with which the host government wishes to treat this topic. Normal practice would be to establish the essential elements of the applicable regime in the Petroleum Law in such a way that the potential investor may easily gain a full understanding of the applicable tax regime, compute without excessive uncertainty the amount of taxes to be paid under such fiscal package, and consider such a fiscal package - taking into account the contractual arrangements - as reasonably competitive with similar worldwide investment opportunities.

As an overview, an appropriate petroleum taxation framework should have the following broad objectives:

(a) to reduce uncertainty regarding taxation to the maximum extent possible. The IOC should have a clear understanding of the taxation regime which applies to it, its affiliates, its personnel, its subcontractors, and to its actual petroleum operations (e.g., imports, exports, turnover taxes);

(b) to limit negotiations on tax issues. Indeed, such issues should ideally be defined in laws and regulations, rather than under a Petroleum Agreement (except for specific procedures and for a number of negotiable issues); 
(c) to provide for a fair and equal tax regime, regardless of the nationality of the investor (i.e., domestic or foreign), without any significant discrimination;

(d) to avoid the double taxation of foreign companies or IOCs by ensuring that profit taxes paid to the host country will qualify for foreign tax credits under the tax laws of the investor's country of origin while, nevertheless, assuring full resource rent capture by the host country; ${ }^{12}$

(e) to provide for tax stability for a reasonable time period. In non-Organization for Economic Cooperation and Development ("OECD") countries, investors are accustomed to benefiting from such stability, even though the host country has the sovereign right to amend tax legislation regularly;

(f) to provide in Petroleum Agreements for reasonable "grandfathering" of tax regimes in existing Petroleum Agreements, unless otherwise mutually agreed; and

(g) to design a tax regime that can readily be applied to any type of Petroleum Agreement which may be entered into (e.g., production sharing contracts ["PSC"], concessions, joint ventures).

Whatever complexity and detail the host government ultimately chooses to include in its fiscal package for petroleum development, experience suggests that certain basic tax premises should be included in the Petroleum Law in order to establish the exact parameters or baselines of the operative fiscal regime excluding all other generally applicable taxes and payments not expressly named therein. The Petroleum Law should cover the following premises:

(a) rights holders under Petroleum Agreements will pay applicable taxes on profits (not revenues) from petroleum operations. ${ }^{13}$ This may be either a specific petroleum profits tax (including additional profits tax ["APT"], as applicable), or the generally applicable profits tax rate;

(b) under a Petroleum Agreement which is a PSC, the rights holder may comply with its obligation in (a) above, by having its tax liability borne by the State

12 This is of particular relevance to IOCs that pay taxes to both the host government and their national State. US-based IOCs are the prime example, and recent changes in UK tax laws have made this principle applicable to UK-based IOCs as well. In such situations, the host government should set its income tax rate at least as high as those generally applicable in the countries of nationality of relevant IOC investors to ensure that the majority of the rent (tax) paid by the investor for the exploitation of the resource is captured by the host government.

13 In the republics of the FSU, this has been a prevalent problem from the outset, creating a significant disincentive to desired foreign investment in the sector. Under various tasks of the Technical Cooperation Program and the ensuing petroleum lending program, considerable progress has been made on this tax policy matter in both Russia and Kazakhstan. 
partner on its behalf. This will be reflected in the production splits available to each party; ${ }^{14}$

(c) under a non-PSC Petroleum Agreement, a royalty (the ceiling and floor of which may be set in the Petroleum Law) will be payable. That royalty will be set from time to time by Regulations consistent with the Petroleum Law, or as negotiated in the Petroleum Agreement; ${ }^{15}$

(d) other payments such as annual rentals, contract administration fees, signature and/or production bonuses may also be payable (as may be negotiated in the Petroleum Agreement), as well as any import and export taxes; and

(e) all other taxes and payments generally applicable to industrial undertakings and enterprises but which are not expressly made applicable to petroleum operations under the Petroleum Law are excluded therefrom.

\section{H. Other Taxes, Duties, ANd Exchange Controls}

While import and export taxes and duties are, as stated in Section II.G above, part of the overall fiscal package, the uniform practice is quite clear regarding their relationship and applicability to petroleum operations. Petroleum Laws and Petroleum Agreements consistently specify that rights holders, and those contractors and subcontractors who work for them, may import and export supplies and equipment authorized under the Petroleum Agreement free of customs duties and taxes of any type. Expatriate employees of these parties receive the same treatment for their household goods and personal effects. To ensure that these exemptions do not become a mechanism for circumvention of the State's regular import controls, any items so imported are subjected to the applicable duties and taxes if they are later sold within the host government's territory. Equally, these exemptions from taxes and duties do not automatically exempt the rights holder from obtaining import and export licences for the goods involved, if applicable. Such licences permit the State both to consider the validity of the exemption on each item to which it applies, and to enforce collections where a sale later occurs within its territory.

With regard to currency and exchange control matters, the Petroleum Law must reflect the reality that to attract significant foreign investment into the sector, the host government should provide certain guarantees regarding the conversion and remittance of funds to investors of risk capital in petroleum operations. Free movement and exchange

14 The rights holder's progressive production shares will be significantly lower, being net of taxes to the host government. For the purposes of the foreign tax credit for US- and UK-based rights holders, it is equally important that production shares received on a "deemed tax-paid basis" include a transparent mechanism by which the applicable tax increment is actually and demonstrably remilted to the host government's tax authorities.

is Despite a minority "hybrid" practice to the contrary, the majority practice is not to have a royalty payable in a PSC Petroleum Agreement arrangement. 
of funds are of particular importance in the international petroleum sector. ${ }^{16}$ At the very least, IOCs are usually assured of the ability to convert and remit the funds needed to meet current obligations and loan commitments. However, it is preferable to ensure that such investors can both convert their local currency profits from petroleum operations at non-discriminatory rates of exchange, and remit them to shareholders without restriction. Admittedly, while this is not always easy for countries with balance of payment problems, it is necessary to foster development of the sector. Provided that the foreign enterprise conducting petroleum operations is in full compliance with its obligations under the Petroleum Agreement, the Petroleum Law should thus permit it to: ${ }^{17}$

(a) bring such foreign currency into the host country as is needed for petroleum operations;

(b) obtain local currency for local purposes from authorized dealers at the most favourable legal rate of exchange at the time of conversion, use local currency available from affiliated companies, and borrow funds in local currency from host country banks, in accordance with the law;

(c) open interest-bearing bank accounts for foreign and local currency;

(d) pay foreign contractors, subcontractors, and expatriate employees outside the host country, provided that it assures that these parties maintain enough foreign currency in the host country to pay taxes and living expenses;

(e) retain abroad all foreign currencies generated from sales outside the host country; and

(f) export any foreign currency funds brought into the host country for petroleum operations which prove to be surplus funds or which result from mandatory sales of petroleum to the State.

\section{FisCal Stabilization}

After a Petroleum Agreement has been concluded, as an additional element of the total fiscal package, the investor should be secured where possible from the adverse economic effects of certain new statutes, regulations, and laws. One way that this may be achieved in both the Petroleum Law and Petroleum Agreement is through the use of certain limited stabilization or renegotiation provisions. These provisions would mitigate the effects of any new enactments which either increase the burdens on rights holders, or reduce their

This is recognized, with some allowance for practical exceptions, by the World Bank Development Committee in Guidelines on the Treatment of Foreign Direct Investment (21 September 1992) [hereinafter Guidelines]. See reprinted in (1992) 7 I.C.S.I.D. Rev. 295. For a detailed analysis of the Guidelines see I.F.I. Shihata, Legal Treatment of Foreign Invesiment: The World Bank Guidelines (Dordrecht, Netherlands: Martinus Nijhoff, 1993).

17 While the above requirements are particularly tailored to the special needs of foreign direct investors in the petroleum sector, they are consistent with the general provisions of Article III, "Treatment," paras. 6.(1) and (2) of the Guidelines, ibid. 
original rights and economic benefits. As a further qualification, the provisions would not apply to new laws imposing safety, conservation, or environmental restraints, areas upon which the State must be free to act in order to protect the public interest. In such cases newly enacted legislation will apply fully to the rights holder. However, this application may be subject to a requirement in the Petroleum Law that the Competent Authority, acting for the State, will negotiate amendments to the Petroleum Agreement in good faith, which would compensate the rights holder for the resulting increased economic burden. ${ }^{18}$ Alternatively, the same result may be achieved without the use of express stabilization provisions. In regions where investment opportunities exist and the investment climate is perceived to be reasonably stable, the State's assurances that all contracts will be scrupulously honoured, subject only to possible limited, non-discriminatory changes enacted for a public purpose, and subject to just compensation for their effect, may well suffice.

\section{J. Environmental Protection and Safety}

International practice in the petroleum sector has lagged behind the pace of much of the world's current keen awareness of the need for diligent environmental protection and preservation. Petroleum Laws often failed to adequately address the topic, and most host countries' modern comprehensive laws on environmental protection and conservation failed to include a substantial backup position. Most frequently, the topic was merely left to a broad and bland obligation in both the Petroleum Law and Model Contract that the rights holder or contractor was typically required to "conduct all petroleum operations in a diligent, conscientious and workmanlike manner in accordance with ... generally accepted standards of international petroleum industry designed to achieve efficient and safe exploration and production of petroleum." Some such provisions went further, requiring that all necessary measures be taken for conservation, safety of life and property, crops, fishing and fisheries, navigation, protection of the environment, prevention of pollution, and safety and health of personnel. While a reasonable beginning, these steps remained inadequate.

Established practice today is to include a more comprehensive obligation for environmental protection and safety in the Petroleum Law, and then to detail more specific actions and requirements in both the Regulations and the Model Contract/Petroleum Agreement. This approach will, almost without exception, include a requirement that an environmental assessment or impact study be carried out prior to the commencement of petroleum operations. ${ }^{19}$ However, such an inclusion may create a

For example, Questions of Production Sharing Agreements when Using the Subsoil, Russian Federation, 29 December 1993. Presidential Decree No. 2285, provides that "[i]f during the period of operation of [a Petroleum Agreement] norms are established by legislative acts of the Russian Federation which worsen the commercial results of the activity of the investor within the framework of the [Petroleum Agreement], changes shall be made therein which ensure to the investor the commercial results which would have been received when applying the norms of legislation that prevailed at the moment of concluding the [Petroleum Agreement]." 
significant short-term financial disincentive. Equally, consistent with the premise that legislative regimes for petroleum development should be self-contained coherent legislative frameworks in and of themselves, it is not recommended that petroleum operations be subjected generally to any existing broad, comprehensive, non-petroleum specific environmental protection law, except to the extent that the principles articulated in such a law are applicable to specific sector practices.

\section{K. Miscellaneous Provisions}

To round out a generic, enabling Petroleum Law, the following topics should be covered briefly but succinctly:

(a) DEFINITIONS: Every law of a technical nature should have a fairly extensive "Definition" section. Every definition should then be used consistently within the law, both for drafting convenience and for accuracy of reference. In order to best serve both purposes, the Definition section should ideally be at the beginning of the law. In Petroleum Laws in particular, accurate and precise definitions are crucial to both clarity and brevity.

(b) Natural Gas Development: It is advisable for the Petroleum Law to provide for special incentives and priorities to encourage the development of natural gas (also a defined term), particularly in host governments which are known to be gas-prone. ${ }^{20}$ Historically, natural gas was treated as the "poor relative" of crude oil. While its potential as an abundant, worldwide, environmentally clean, and economically efficient fuel, is now well recognized, Petroleum Laws still often do not make adequate provision for its economic development. Enlightened modern Petroleum Laws contain specially tailored gas development and commercialization provisions to encourage positive action on gas discoveries. These include, inter alia, provisions to appraise for the State (even if the rights holder does not wish itself to attempt commercial development), allow the rights holder a longer development or retention period to conduct a market feasibility study, and the option to develop the discovery jointly with the State in a negotiated joint venture. In summary, practice today dictates that when a Petroleum Law is drafted for a host country known or likely to be gas-prone, it should include special gas development provisions such as those mentioned above.

(c) UNITIZATION: When rights holders on adjacent blocks know, prove, or have reason to believe that they each have discovered petroleum from a common structure which extends across the boundary line of their respective blocks, the State has a paramount right to ensure that in the interests of economy, efficiency, and conservation of the resource, the common deposit is developed by the

petroleum projects, see Environmental Assessment Sourcebook, vol. 3, Guidelines for Environmental Assessment of Energy and Industry Projects (World Bank Environment Department. 1991). 
interested rights holders as a single unit, and on a non-competitive basis. This procedure is called "unitization." Unitization prevents wasteful competitive drilling by rights holders to the prejudice of the State's interests as the resource owner. Common practice is to include a provision in the Petroleum Law giving the Competent Authority the right to order the affected rights holders to develop such an area jointly, or under a joint operating or unit plan approved by the Competent Authority.

(d) ACCESS TO LAND FOR PETROLEUM OPERATIONS: Legislative frameworks for petroleum E\&P development should, to the greatest extent possible, be selfcontained and coherent, and issues of land use for petroleum operations should be both specifically addressed in the Petroleum Law, and harmonized therein with any broader-based land law in force. The Petroleum Law should guarantee the rights holder access to both public and private lands for the purposes of carrying out procedures necessary and incidental to its petroleum operations. The conditions of such qualified rights of entry and use should be articulated in the Regulations made by the Competent Authority. Those Regulations should also include a provision for payment of fees to the State as consideration, and compensation to landowners and occupiers whose rights have been disturbed. Presumably, the State will already have the power to appropriate or burden private lands temporarily for public policy purposes (i.e., for petroleum development) against the payment of adequate compensation under the broader land law. If not, such a provision should be specifically included in the Petroleum Law for the purpose of facilitating petroleum operations. ${ }^{21}$

(e) INTERNATIONAL ARBITRATION: Certain disputes between parties to a Petroleum Agreement (i.e., a foreign IOC and the Competent Authority) which cannot be settled by other means should be made referable under the Petroleum Law, at the request of either party, to settlement by international arbitration under the rules and auspices of one of the recognized international arbitral fora. However, not all disputes should be made subject to such international arbitration. Those to be arbitrated should be limited strictly to controversies involving the interpretation, validity, execution, or termination of a Petroleum Agreement. Assurances that such disputes will be decided by a knowledgeable and impartial decision-maker is of particular importance in the international petroleum sector. Furthermore, controversies involving laws or regulations not directly related to the Petroleum Law remain within the jurisdiction of the host country's courts. Recognized and suitable international arbitral fora include: International Center for Settlement of Investment Disputes ("ICSID"), a Bank affiliate, the Stockholm or London Courts of Arbitration, the court of arbitration of the International Chamber of Commerce in Paris, and the arbitration centers of the Afro-Asian Legal Consultative Committee in Cairo and Kuala Lumpur. Both the host government and explanation, for example, with Russian counterparts under the Petroleum Legislation Task of the Technical Cooperation Program. 
and the State of the IOC's nationality would have to be a party to those fora established by international conventions, such as the ICSID.

(f) AfFected Legislation/Relationship to OtHer LaWS: the Petroleum Law must clearly state its relationship to other relevant legislation. The current practice is that all matters concerning petroleum should, to the extent possible, be covered by the Petroleum Law. If this is not possible, the Petroleum Law should, at the time of its promulgation, specifically be made to prevail over any conflicting requirements of other existing laws or regulations. Such conflicting laws and/or regulations should subsequently be amended to remove such conflicts, and the principle of precedence of the Petroleum Law should be clearly enunciated therein. However, as an intermediary step, the Petroleum Law may specify certain transitory periods or delays to its full force and precedence, pending other necessary legislative action or the making of amendments to conflicting provisions of other laws.

\section{Regulations to a Petroleum Law}

The second essential component of successful petroleum legislative frameworks for E\&P development are the Regulations to the Petroleum Law. As discussed in Part I above, the Petroleum Law should expressly authorize the Competent Authority to make Regulations which provide the detail and procedures by which the policy and objectives of the Petroleum Law are to be implemented with reference to specific enabling provisions thereof. As also discussed above, the Regulations are subsidiary instruments to the Petroleum Law not intended for legislative consideration or enactment. The benefit of this practice is that maximum flexibility is maintained, allowing for a timely response to any current developments which would require changes in the Regulations. The safeguard is that the Regulations, and any changes thereto, should never be inconsistent with either the policy, objectives, or letter of the Petroleum Law.

Consistent with the types of legislative formats discussed here, the Regulations to the type of Petroleum Law detailed in Part 1 above will follow the Petroleum Law's format, adding the detail necessary to effect the intent of its enabling provisions. Such Regulations may or may not be quite extensive, this depending on many factors. However, regardless of length or brevity, particular attention and elaboration in the Regulations should always be given to the core items that follow.

\section{A. COMPETEnT AUTHORITY}

In the event that the Petroleum Law itself does not identify the single government entity or agency that will act as the Competent Authority, that entity or agency should be identified in the Regulations. The policy advantage of such an approach is flexibility. The concept of the Competent Authority must be established by law, but its identity may be more readily changed by Regulation, thereby incorporating the ability to respond to evolving circumstances and growing or shifting expertise within government. However, based on experience, a necessary caveat is that frequent changes in the identity of the 
Competent Authority will prove a disincentive to foreign investment due to the perceived instability and the lack of continuity.

To the extent that the exclusive mandate of the Competent Authority to implement State policy in the petroleum sector does not fully enumerate within the Petroleum Law all of the Competent Authority's specific powers and duties attendant thereto, the practice is to set them out in detail in the Regulations. It is also possible to address in the Regulations the structure and composition of the Competent Authority, but it would be better to do so in a separate constitutive document or decree, as this is more an administrative matter than one of sectoral substance.

\section{B. Petroleum Licensing}

As the Petroleum Law establishes both that the State exclusively owns all petroleum within its territories, and that it may conduct operations through any entity or in any manner in order to develop such petroleum - including the licensing of its exclusive right to qualified applicants under a Petroleum Agreement - the Regulations must detail the methods by which such licensing may be accomplished.

Established practice is to first delimit prospective petroleum acreage, and then to offer it for licensing by officially and publicly advertised bid tenders. However, where acreage is not included in such a bid tender, the Competent Authority should also be permitted by the Regulations to enter into direct negotiations for the licensing of acreage by an interested party upon its valid application. But, in order to receive the most competitive offers, bid tender is preferred where petroleum industry interest is either anticipated or evident. ${ }^{22}$ The elements to the bid tender process include:

(a) CONTRACT AREA: Before licensing procedures can commence, the Competent Authority must first accurately identify the areas to be offered. Standard practice is to provide for the principle of "graticulation" (geographic demarcation) in the Petroleum Law, and then to deal more specifically with these areas in the Regulations. In this regard, the Regulations should specify a uniform shape for areas to be offered (i.e., the Contract Area). Generally, the Contract Areas should be geometrically regular in shape - normally a 3 to 1 rectangle - oriented north/south or east/west. The usual practice with respect to the size of the Contract Area is to specify in the Petroleum Law both the minimum and maximum areas to be allowed (in square kilometres), leaving the Competent Authority to determine individual Contract Areas within these permitted limits.

(b) BID TENDERS: The Regulations should outline in detail the procedures by which bid tenders will be conducted. This is subject to numerous variations, but should always cover, inter alia: 
(i) issuance of a bid package by the Competent Authority which includes an accurate map of the area(s) open for bid; a brief description of the geology and topography of the offered area(s); a bid sheet listing the criteria for bid evaluation and providing a format for bidders to submit their proposals; a Model Contract(s) where bidders must identify any exceptions; the procedure for submission and evaluation of bids and the subsequent negotiating process; and the amount of any bid guarantee to be submitted, set at an amount both to encourage the widest competition and to discourage less than serious bids. ${ }^{23}$

(ii) the requirement that the Competent Authority shall publish a brief description of the area(s) to be subject to the bid tender, the proposed petroleum operations to be conducted (e.g., new exploration, development, enhanced recovery, or workover), and instructions for obtaining bid packages in the official government journal or newspaper. The Competent Authority should also be given discretion both to publish similar notices in domestic and foreign business and trade publications, and to send them directly to bidders that the Competent Authority believes may be interested. ${ }^{24}$

(iii) the discretion of the Competent Authority to require prospective bidders to purchase geological and geophysical data, well logs, or other proprietary information owned by the State concerning the area(s) subject to the bid tender. In such a case, the Regulations should require that the description and price of the bid package shall be included in the notice to prospective bidders (discussed in (ii) above). The preferred practice regarding the price charged for bid packages is to limit it to an amount adequate to cover the cost of its production and/or the administrative costs of the bid tender. ${ }^{25}$

(iv) the processes and procedures of bid submission, evaluation, award, and negotiation of a Petroleum Agreement. In particular, provision should be

The evil to be prevented here is "promotion" by an applicant which does not have either the financial or technical capabilities to fulfill the proposed minimum work obligation. Too often, States new to the sector will award licences to such companies under questionable circumstances, which such companies will, in turn, seek to sell, assign or "farm-out" all or most of their rights to an IOC at a significant profit, having made no real monetary or work expenditures. While the World Bank will not comment directly to a host government on the merits of any such licence or Petroleum Agreement awarded, it will seek, if requested, to demonstrate to the host government best practice in the sector, as a comparison or benchmark. Under Bank-financed Petroleum Exploration Promotion Projects, in addition to broad, international trade publication of intended licensing rounds by host governments, such projects include a component for one or several promotion seminars for interested industry companies in the host government's capital city, as well as in international oil centers such as London, Houston, and Singapore.

The preferred practice is for the host government not to seek to make a significant profit on the sale of bid data packages. This can be a real disincentive to attracting industry interest. The more difficult case is where a State contracts with a private geophysical company to acquire and prepare a data package for sale at cost plus a profit margin to the independent contractor. 
made for (a) the submission of sealed bids, (b) their public opening, and (c) procedures for their evaluation and a maximum time limit for the Competent Authority to conclude the process and to negotiate a Petroleum Agreement. The procedure is to rank in order of their merit all responsive and competitive bids - factoring in an evaluation of the bidder's technical and financial competencies - and to notify the first several (for example, three) ranked applicants. Thereafter, the Competent Authority will begin negotiations with the highest ranked bidder based on the Model Contract. The mandate of those negotiations is to conclude a Petroleum Agreement within a maximum time limit (for example, sixty days). If an agreement is not reached within that time limit, the Competent Authority may commence fresh negotiations with the next ranked bidder(s). Alternatively, the Competent Authority may reject all bids and either re-bid the area(s) or withdraw all or part of it from the bid tender.

(c) DiReCt NEgotiations: As stated above, acreage which is not included or planned to be included in a bid tender should be permitted by the Regulations to be licensed by the Competent Authority through direct negotiations. A party interested in entering into direct negotiations with the Competent Authority should provide the Competent Authority with information sufficient to fully identify several areas: itself, as a corporate or other entity; its area of interest, defined by geological coordinates; its technical competence and financial resources, fully described and documented; and complete terms and conditions it proposes for a Petroleum Agreement. Thereafter, at the Competent Authority's discretion, it may enter into such direct negotiations with the applicant on such terms as it may deem appropriate, provided that they are consistent with both the Petroleum Law and the Regulations.

\section{Petroleum Operations}

Under this heading, the Regulations should address specific requirements to be met in the carrying out of petroleum operations under a Petroleum Agreement. The most important of these normally include:

(a) the submission to the Competent Authority of the rights holder's annual work program, timing, and procedures for its approval;

(b) the prompt supply by the rights holder to the Competent Authority of quality copies of all geological, geophysical, well, and other technical data developed for a contract area to be the subject of a Petroleum Agreement;

(c) the rights holder's obligation to use only the best available machinery, equipment, and supplies in petroleum operations, in accordancewith international best practice; 
(d) the rights holder's guarantee of reasonable and timely access for Competent Authority personnel to all areas upon which petroleum operations are conducted under a Petroleum Agreement;

(e) the rights holder's obligations with regard both to advance notification to the Competent Authority of the drilling of any proposed well and the former's duty to plug and abandon unsuccessful wells in an environmentally and safetyconscious manner; and

(f) the requirement and procedures by which the rights holder, under a Petroleum Agreement, must meter and measure petroleum produced and transported from a Contract Area for the purpose of accounting for it to the Competent Authority.

\section{Petroleum Agreements}

Some Petroleum Laws have attempted to legislate the entire content, in detail, of what must be included in a Petroleum Agreement. ${ }^{26}$ Some Regulations go into extensive detail in lieu of legislating it in the Petroleum Law. The former option is definitely not recommended; the latter, while less disfavoured, is normally counterproductive. As noted earlier, it is better to have the Petroleum Law enact the core concepts of the legislative, contractual, and fiscal regime (in broad outline but not in specific detail) and for the Regulations to elaborate such core concepts, as necessary. The actual contents of the proposed Petroleum Agreement (consistent with the essential requirements set out in both the Petroleum Law and Regulations) ideally would be contained in a Model Contract, which, as a subsidiary non-enacted instrument, would be the starting point for the State's negotiations of Petroleum Agreements.

Consistent with this legislative scheme, the Regulations, in amplifying the enabling provisions of the Petroleum Law, should address the following essential Petroleum Agreement points:

(a) CONTRACT PHASES: the Regulations should clearly establish that E\&P Petroleum Agreements articulate separate and distinct phases including exploration, appraisal, and exploitation or development periods. The Regulations should not specify mandatory terms for each phase but instead should set maximum periods for each while providing for the possibility of a defined number of extensions of a maximum term for each. ${ }^{27}$ The actual phase terms to be agreed with each rights holder should then be negotiated, within the specified maximums, and set out in the appropriate clause of the Petroleum Agreement. Table 4 exemplifies these various stages.

As was the case with the original draft Petroleum Law prepared by non-Bank-financed legal consultants for Azerbaijan. Under the proposed Energy Sector Technical Assistance Project for this member, such an approach will be abandoned and a Petroleum Law, of the type discussed in this article, will be prepared.

$27 \quad$ This might be, for example, a maximum of five years for exploration, with up to three extensions of one year each; a maximum of twenty-five years for development, with up to two extensions of five years each. 
(b) MINIMUM WORK OBLIGATIONS ("MWO"): the Regulations should mandate that Petroleum Agreements will provide for defined, minimum petroleum operations to be performed by the rights holder during each phase of the contract, or other periods of time within such phases. These MWOs must be expressed in quantitative terms (for example, number of wells and/or metres to be drilled, kilometres of seismic lines to be acquired) or in monetary terms (monetary value of each MWO committed). However, preferred practice is that the MWO be expressed in quantitative work obligations with line-item monetary values assigned to each such obligation. In addition, the Regulations should stipulate that those monetary values are payable as a penalty in the event of their nonfulfilment. ${ }^{28}$ The Regulations should also establish the principle that, while the rights holder may credit work undertaken in excess of the MWO for a given term to an ensuing term, its failure to perform the MWO for any given term will give rise to penalties (such as the payment to the Competent Authority of the value of the MWO not completed, termination of the Petroleum Agreement, or both). To ensure that the Competent Authority will receive payment for the value of MWO items not completed, the Regulations should specify that the rights holder must secure either a bank guarantee, or an irrevocable standby letter of credit in favour of the Competent Authority. That letter of credit should secure, on a lineitem basis, the total value of the applicable MWO. It should also stipulate that the Competent Authority may draw down on demand in cases of nonperformance or default.

(c) RELINQUISHMENTS: consistent with international practice, the Regulations should require that Petroleum Agreements provide for periodic relinquishments of contracted acreage during the course of the exploration phase and any extensions thereto. This will be done within both the times and the percentages set forth as guidelines in the Regulations and then negotiated as firm commitments in the Petroleum Agreement. ${ }^{29}$ The objective of such periodic relinquishments is to ensure that, by the end of the exploration phase of a Petroleum Agreement, the rights holder will return to the Competent Authority, in an orderly geometric pattern, all acreage contracted but not commercially developed which is suitable for re-offering under a subsequent Petroleum Agreement.

Recently some states have adopted a system of "work units," where certain activities such as seismic or drilling are allocated a "work unit" value. The IOC then commits to perform a certain number of work units as part of its minimum work obligation during a particular phase. The advantage of this system is that it provides the $1 O C$ with the freedom to determine how to execute its work obligation (i.e., through drilling one deep well rather than two shallow ones, or by preferring additional seismic work over drilling activity), while still giving the host government the assurance that valuable work will be performed. Failure to perform the number of work units required for a particular phase results in the payment of a penalty for the number of unperformed work units, at a stated value for each work unit. 


\section{Exploration Period}

\section{Sample Exploration Period}

First Phase - Three Years

-Conduct various geological/geophysical studies/field work

-Reprocess/interpret 1000 kilometres of seismic (assuming seismic already exists within the area)

-Shoot, process, and interpret 1000 kilometres of new seismic

-Drill one exploration well

Contractor shall have the option to drop the area after completion of this work or elect to move into the Second Exploration Phase.

Second Phase - Two Years

-Conduct further geological/geophysical studies deemed necessary by the Contractor

-Shoot, process, and interpret $\mathbf{5 0 0}$ kilometres of new seismic

-Drill one exploration well

Contractor shall have the option to drop the area after completion of this work or elect to move into Third Exploration Phase.

Third Phase - Two Years

-Contract additional geological/geophysical studies deemed necessary by Contractor

-Shoot, process, interpret seismic deemed necessary by Contractor -Drill two exploration wells

Contractor shall have the option to drop the area after completion of one of the exploration wells provided for in this Phase.

\section{E. Fiscal and Financial Regime}

As indicated above, regardless of the complexity of the final fiscal regime chosen, its essential elements should be set out generically in the Petroleum Law and then treated with more detail in the Regulations. The advantage as of such an approach is the ability to easily change particular rates and percentages in response to evolving circumstances, while maintaining consistency with the principles and guidelines established in both the Petroleum Law and in the individual Petroleum Agreements. Thus this section of the Regulations may: 
(a) set the flat rate or range of a sliding scale negotiable royalty, if one is to be payable under a non-PSC regime;

(b) set the rates or ranges for land rental and/or contract administration fees, payable annually to the Competent Authority;

(c) establish the points during petroleum operations when bonuses may be payable (based on, for example, signature, commercial discovery, or production levels), normally as quantitatively agreed in a Petroleum Agreement;

(d) under a PSC regime, indicate both the acceptable ranges of production splits for profit oil, as between the State and the rights holder (the latter on an income tax deemed-paid basis), at indicative levels of production, as well as the acceptable ranges or levels of cost recovery allowable to a rights holder out of cost oil, all as may finally be negotiated in a Petroleum Agreement; ${ }^{30}$ and

(e) in a tax and royalty regime (i.e., non-PSC), confirm the application or limitation of the generally applicable profits tax on rights holders' petroleum operations profits and/or provide the rate of any petroleum revenue tax ("PRT") in lieu, and set rate ranges for any additional profits tax ("APT"), leaving its applicable thresholds to be negotiated in a Petroleum Agreement. ${ }^{31}$ See Table 5 for an example of a simplified royalty and tax methodology calculation.

The indicative levels of production will normally be at steps from 25,000 to 50,000 to 100,000 to 150,000 to in excess of 200,000 barrels of oil per day ("BOPD") for normal commercial fields. A 30 to 50 percent range of cost recovery is quite normal. Above 70 percent would be generous, but a definite incentive to investment where prospects may be thought to be marginal. development of normal or marginal oilfields, however, the thresholds of cumulative or gross production at which APT attaches should be set quite high. 


\begin{tabular}{|c|c|c|}
\hline \multicolumn{3}{|c|}{$\begin{array}{l}\text { A Simplified Example of the Royalty and Tax Methodology Calculation for } \\
\text { A Licence or Concession Might be as Follows: }\end{array}$} \\
\hline 1. & Gross Daily Production & 100,000 BOPD \\
\hline 2. & Royalty Payable to the State -15 percent & $\underline{15,000 \mathrm{BOPD}}$ \\
\hline & Gross Production Less Royalty & 85,000 BOPD \\
\hline 3. & Contractors Operating Expenses, Other Tax Deductions & 10,000 BOPD \\
\hline & Net Taxable Income & 75,000 BOPD \\
\hline 4. & PRT -40 percent of Net Taxable Income & 75,000 BOPD \\
\hline & Contractors Share of Production & 45,000 BOPD \\
\hline & State's Net "Take" & 45,000 BOPD \\
\hline
\end{tabular}

The practice here is to specify in the Regulations that, with regard to accounting for revenues and profits from petroleum operations, the rights holder will maintain clear and accurate records in an agreed unit or currency of account, consistent with international petroleum industry standard accounting practice. They will also provide periodic (e.g., monthly or quarterly) reports thereon to the Competent Authority, pursuant to the requirements and formats contained in an Accounting Procedure mandatorily appended to the Petroleum Agreement.

Finally, this section of the Regulations should set forth an internationally recognized method by which to value crude oil and natural gas produced from a Contract Area, ultimately to be agreed and confirmed in a Petroleum Agreement.

\section{F. ASSIGNMENT OF RightS}

As a rights holder may often subsequently wish to transfer or assign all or a portion of its rights either to its own affiliate, to another member of its consortium (if applicable), or to a third party, the Regulations must address such a process expressly. The practice is to allow such assignments as follows:

(a) to an affiliate, ${ }^{32}$ on prior notice to the Competent Authority, and without the

32 An "affiliate" will be a defined term in the Model Contract or Petroleum Agreement. The operative part of the definition will be that the contractor owns, directly or indirectly, a majority of both the equity and voting control of the affiliate. While the best practice is to allow an assignment to an affiliate on notice to the Competent Authority but without the need for its prior consent, this will 
necessity of its prior consent. However, the assignor remains liable for the performance of the agreed MWO;

(b) to other consortium members, with a minimum of thirty days prior notice to the Competent Authority and with consent therefrom. Such consent cannot be unreasonably withheld; and

(c) to a third party, with a minimum of sixty days prior notice to the Competent Authority, and with consent therefrom. Such notice must include all information concerning the proposed transferee which is required of an applicant for a licence or permit. The notice must also include an unconditional undertaking by the proposed transferee to be bound by all of the transferor's obligations under the Petroleum Agreement. ${ }^{33}$

Thus any such transfer or attempted transfer or assignment (other than (a) above) without the express approval of the Competent Authority would be null and void, and would constitute valid grounds for termination of the Petroleum Agreement.

\section{G. LAND USE}

As noted above, the Petroleum Law must guarantee the rights holder necessary access to public and private lands in order to carry out petroleum operations. In this regard, the practice is for the Regulations to require the Competent Authority to deliver to the rights holder, at the time of its signing the Petroleum Agreement, all licences and permits required under existing legislation for the conduct of petroleum operations. These include those licences and permits which allow the rights holder to reasonably use public and private lands, roads, means of communication, water, and minerals. Where privately owned land is to be so encumbered, the practice is for the Regulations to require good faith negotiations by the rights holder with the landowner(s), and a compensation payment to them if a voluntary agreement is reached. If a voluntary agreement is not reached, the Regulations should empower the Competent Authority to institute proceedings under the applicable land law for the temporary or permanent taking of such lands by the State on behalf of the rights holder. The rights holder must pay both the adjudicated just compensation to the landowner, and the administrative costs which it incurred by having undertaken and conducted such proceedings to the Competent Authority.

\section{H. Environmental Protection}

The evolving practice is to amplify the obligation for environmental protection in the Petroleum Law with specific details and required actions found in both the Regulations and the Model Contract. The Regulations may be as detailed as deemed necessary, but in

always be coupled with contractor/assignor's ongoing liability under the Petroleum Agreement on a joint and several basis with its affiliate.

"3 Where assignment is to be to a third party, the contractor/assignor must first show that it is either current on its MWO, or that the contractor/assignor and the proposed assignee jointly and severally guarantee its satisfactory completion. In this regard, it must be clearly demonstrated to the Competent Authority in the assignment application that the proposed assignee has the requisite financial and technical resources to carry out the petroleum operations. 
the process of establishing norms of conduct, they should focus on the broad principles of:

(a) minimizing ecological damage;

(b) avoiding waste of petroleum and its production environment;

(c) preventing pollution and waste to land and structures, fresh water resources, crops, and marine and animal life;

(d) establishing emergency clean-up obligations and procedures; and

(e) restoring the environment at the conclusion of petroleum operations.

\section{Miscellaneous Provisions}

Regulations to a Petroleum Law may be quite extensive or not; this depends on many variables. The length or brevity of the Regulations should not be a determining factor, but rather, the Regulations should provide the necessary detail and procedures required for the full implementation of the policy and objectives of a generic Petroleum Law. Within this overriding parameter, some items may be deemed more important than others, and will thus receive more detailed treatment in the Regulations. This will vary considerably from State to State, depending on legal systems and sectoral or national priorities.

This section concludes by briefly enumerating other important items which may require special consideration and elaboration in Regulations to a Petroleum Law:

(a) DEFINITIONS: the established practice is to incorporate by reference into the Regulations all definitions from the Petroleum Law and then to add, as necessary, any additional definitions which may be required;

(b) RECORDS AND REPORTS: under the Regulations and the Petroleum Agreement, the rights holder must keep for review by the Competent Authority full and accurate technical, geological, and geophysical records of all petroleum operations conducted, and must report regularly to the Competent Authority as required by the Regulations;

(c) ACCOUNTS: pursuant to the Regulations and pursuant to the agreed schedule in the Petroleum Agreement, the rights holder must also maintain and periodically submit to the Competent Authority full and accurate accounts of all quantities and qualities of petroleum produced from the Contract Area and its ultimate disposition; ${ }^{34}$

That is, either sold or refined, in the case of crude oil; or, in the case of natural gas, reinjected, treated (e.g., removal of natural gas liquids), or flared, if the latter is permitted by the law of the host government. In addition, a certain amount of production may be validly consumed by the contractor in conducting petroleum operations. 
(d) PRODUCTION RATES: the Competent Authority is generally discouraged from setting or mandating production rates for reservoirs and Contract Areas. Instead, the international standard which the Regulations should recognize is the maximum efficient rate ("MER"), which is the rate of production from a reservoir which achieves the maximum ultimate economic recovery of petroleum;

(e) MEASUREMENT OF PETROLEUM: the Regulations should require the rights holder to measure, meter, and weigh all petroleum produced by methods customarily used in good oilfield practice, as approved by the Competent Authority, and to periodically test and recalibrate, as necessary, all such equipment used in the processes;

(f) CONFIDENTIALITY: the Regulations will mandate, and the Petroleum Agreement will amplify, the obligations of both the rights holder and the State to maintain for defined periods the confidentiality of information, documents, data, and materials related to a Contract Area and acquired or exchanged between them in the course of petroleum operations; ${ }^{35}$

(g) INDEMNITY: the Regulations should require the rights holder under a Petroleum Agreement both to indemnify the State or the Competent Authority, and to indemnify it from all loss or damage to third parties or property caused by or occurring in the course of the conduct of petroleum operations; and

(h) PENALTIES: the Regulations will set out offences to the Petroleum Law and the Regulations, along with a schedule of penalties for individuals or corporate entities found guilty of any such offences.

\section{J. MODEL FORMS}

To facilitate an application for a licence or permit to conduct petroleum operations under a Petroleum Agreement, it is useful to append to the Regulations the model forms to be used by the applicant or prospective rights holder in making such application either under a bid tender or for direct negotiations. These model forms will be keyed to specific requirements in the Petroleum Law and Regulations, covering such basic requirements and information as:

(i) basic information regarding the applicant;

(ii) Contract Area application/bid;

(iii) proposed schedule of bonuses; and

is Typically, the Competent Authority may disclose data obtained from the contractor's conduct of petroleum operations to prospective new applicants for portions of the Contract area already relinquished by the contractor. Otherwise, both the Competent Authority and the contractor are bound to complete confidentiality during the term of the Petroleum Agreement (absent mutual consent otherwise), and the contractor for anywhere from three to eight years after the termination of the Petroleum Agreement, unless the data in question earlier becomes part of the public domain. 
(iv) land rentals and administrative service fees.

\section{MODEL CONTRACT}

The final essential component of successful petroleum legislative frameworks is one or several variants of a Model Contract. Despite some disagreement within the industry on the necessity of this element, a State is best served by having its own purpose-crafted contractual format from which to commence the negotiation of Petroleum Agreements. The Model Contract(s) should be included in the bid tender package, requiring applicants to identify any exceptions thereto as part of their bid.

The contents of a Model Contract will flow from the permissive, generic requirements of the Petroleum Law, as elaborated more fully in the Regulations. In this regard, this section will focus on both the essential provisions of a Model Contract, and those which are negotiable.

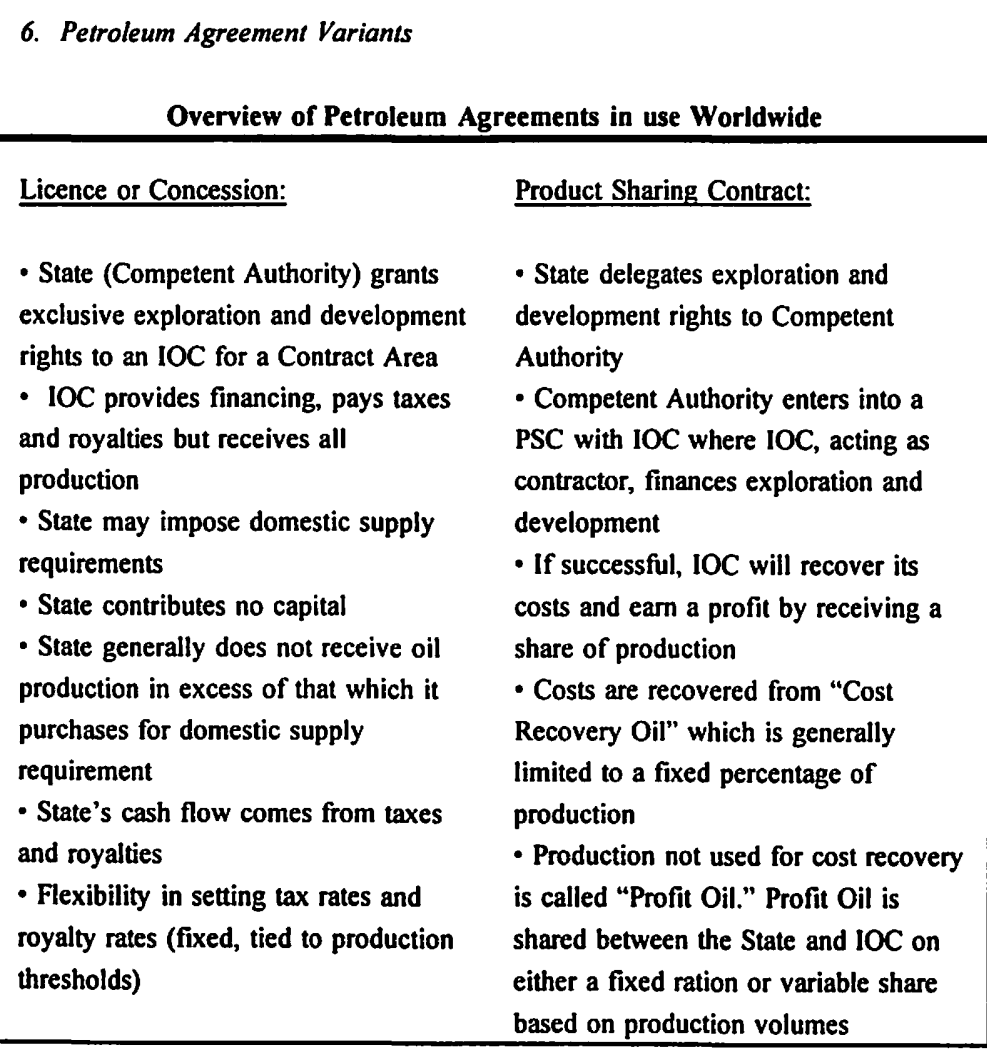


Association Contract:

- IOC and NOC form a joint venture

- NOC pays its share of expenditures, although it may be carried through the exploration and development phase

- NOC and IOC each receive share of production in proportion to their equity contributions

- IOC pays royalty, income tax, and usually some form of PRT

- Association Contract creates the economic incentives of licence agreement by giving $\mathrm{IOC}$ an equity stake but provides control to the NOC by maintaining the IOC's role as contractor rather than a concessionaire

\section{Service Contract:}

- IOC pays all exploration and development costs

- IOC recovers these expenditures through a discounted crude purchase price, cash payments, or production take

- State retains entire production upside, although it may grant a negotiated sliding share of oil produced ("Risk Service Contract")

- IOCs generally dislike being a service contractor to the State. Thus this form of contract is infrequently used

\section{A. SCOPE, DURATION, AND GRANT OF Rights}

The Model Contract should contain a brief preamble which identifies the parties (State or Competent Authority and rights holder, the "Contractor"), which reaffirms the State's exclusive ownership of all petroleum in its territory, and which expresses the State's satisfaction that the prospective Contractor has the requisite experience, financial and technical ability, and resources to carry out petroleum operations. This preamble is followed by an extensive definition section which tracks those definitions used in the Petroleum Law and Regulations. The Model Contract will then set out articles dealing with the following:

(a) SCOPE: the Model Contract will make it clear that it contains the entire agreementbetween the State/Competent Authority and the Contractor concerning petroleum operations in the applicable Contract Area. In addition, it will identify the negotiated Contract Area in square kilometres and by geographical coordinates (as referenced in an attached map), and will define the scope of the agreement, including rights and obligations, between the parties.

(b) PERIODS, PHASES, AND TERMS: three periods must be considered: exploration, appraisal, and production. The terms for each period are negotiable, subject to the maxima and to extensions as set in the Regulations. These terms will also establish that the Contractor may relinquish and terminate at the end of either the exploration or appraisal stages, provided that it has satisfied the MWO for each.

(c) GRANT OF RIGHTS: the Competent Authority will grant the Contractor its rights over the entire agreed Contract Area for the duration of a Petroleum Agreement. It will make this grant effective upon execution by both parties of a Petroleum Agreement. 


\section{B. MWO, Work Program, and Guarantees}

These are essential core provisions. The proposed MWO will have been submitted in the bid and will be subsequently negotiated. The Model Contract provides a format to insert the MWO agreed for the exploration period, and any extensions thereto, by contract year. These will be defined obligations to carry out additional agreed geological and geophysical work, and to drill a minimum specified number of exploratory wells. The MWO will be carried out through an annual work program and budget which will require approval by the Judgment Management [Advisory] Committee ("JM[A]C"), discussed in Section E below.

To support the MWO and the annual work program, the Model Contract should require the Contractor to provide an unconditional bank guarantee or standby letter of credit in favour of the Competent Authority. This guarantee or letter of credit should set out the negotiated amount of such a guarantee for each phase of the exploration period by line item. ${ }^{36}$ Provision is then made for the scheduled reduction of the guarantee when the Competent Authority certifies to the issuing bank that the work in question has been completed. In addition, it is desirable to have a guarantee from the ultimate parent company of the Contractor that it will provide all technical and financial resources that are required by its subsidiary in order to conduct petroleum operations. ${ }^{37}$ The approved form of guarantees will be appended to the Model Contract.

\section{RELINQUISHMENTS}

Mandatory relinquishments by the Contractor during the course of the exploration period will be negotiated and inserted as progressive percentages of the original total Contract Area. At the end of the exploration period, the Contractor will have either relinquished the entire Contract Area (having fulfilled its MWO), or it will relinquish all but those portions in which it has made a commercial discovery of petroleum that it will then go on to develop.

\section{Declaration of Commercial Discovery}

This elaborates the process by which a discovery of petroleum may be deemed sufficient for commercial development. No matter how expressed in the Model Contract, the key principle is that only the Contractor may decide if a discovery is commercially viable for the purposes of its subsequent development. After promptly reporting a discovery to the Competent Authority, the Contractor must first elect whether to appraise it. If it chooses not to do so, it must immediately relinquish the discovery area. If it does

36 For example, a contractor's MWO may require the drilling of at least two exploration wells during the initial exploration term. If the Contract Area were to be offshore, in moderate water depth, such wells might average $\$ 5,000,000$ US each. The guarantee or standby letter of credit would thus carry each such commitment well and its value as a line item, to be either reduced accordingly when completed, or drawn down, in case of default on such item by the contractor.

While such a guarantee is desirable and often obtainable, parent companies will rarely go as far as providing a full, unconditional financial guarantee of the contractor under a Petroleum Agreement. Instead, they will offer a comfort letter, affiliate guarantee, or bank guarantee. Properly drawn, the latter two could provide adequate assurances to the host government. 
elect to appraise a discovery, it must do so within a specified time period, under a separate appraisal program, and then it must submit an evaluation of the appraised discovery to the Competent Authority. Then the Contractor alone decides whether the discovery is commercially viable, thus warranting its development. The firm principle is that the State or Competent Authority may not impose greater obligations on the Contractor than it had agreed to under its Petroleum Agreement (i.e., to compel it to develop by deciding commercial viability contrary to the Contractor's own judgment). The fact that the Contractor must relinquish the appraised discovery if the Contractor decides it is not commercially viable provides the State with a safeguard.

\section{E. JoInt Management [Advisory] COMMITTEe}

The $\mathrm{JM}[\mathrm{A}] \mathrm{C}$ is the consultative forum and supervisory body for petroleum operations under PSCs or association contracts. It is composed of equal numbers of state representatives and representatives of the Contractor. Its chairman is typically appointed by the Contractor during the exploration period. Decisions of the JM[A]C are normally taken unanimously or by consensus. In the event of a deadlock, the usual practice is that the Chairman has the casting vote. Although the JM[A]C's functions are in the nature of supervision over certain matters under the Petroleum Agreement, they are always without prejudice to the rights and obligations of the Contractor for the day-to-day management of petroleum operations. Thus the scope of the JM[A]C's authority is normally quite limited, but will usually encompass:

(a) all work programs, budgets, and other reports and proposals required under the Petroleum Agreement to be submitted to the Competent Authority;

(b) progress of the Contractor's work;

(c) terms of contracts with subcontractors, and their performance; and

(d) any problem arising in the conduct of petroleum operations.

The JM[A]C may also form technical subcommittees which act as forums for consultation and as a conduit for the transfer of technology. They also provide know-how between the Contractor and the State or Competent Authority.

\section{F. Cost Recovery, Expenses, and Production Shares}

If dealing with the majority preferred Model Contract that utilizes sliding scale production sharing, ${ }^{38}$ this section of the Model Contract will: (a) be subject to the Accounting Procedure and the auditing provisions of the Model Contract, and provide for Contractor's cost recovery, which, as explained earlier, may be bid and negotiated within

While this analysis is based on the sliding scale PSC Model Contract variant, one may also vary the basic Model Contract format to produce other standard arrangements, including: licence or concession with tax and royalty; Risk-Service Contract or Service Contract. Much of the essential elements of the Model Contract will be the same, with the principle changes being in the MWO and fiscal provisions. 
the acceptable ranges or levels of percentages of cost oil established in the Regulations; (b) detail the manner in which operating, capital, and pre-commercial production costs and expenses shall be allocated and recovered against cost oil; and (c) set out the shares of profit oil due to the State or Competent Authority and the Contractor which is based on average daily production over a contract month from the Contract Area, and in proportions to be bid and negotiated within the acceptable ranges established in the Regulations. ${ }^{39} \mathrm{~A}$ similar provision will be made for natural gas in a modern contractual framework. ${ }^{40}$

\section{G. TAXes AND Duties}

Under a sliding scale PSC Model Contract, the Contractor's taxes are deemed paid within its progressive (or regressive) production shares. The Competent Authority, on the State's behalf, will undertake to insulate the Contractor from all present and future host government taxes and duties otherwise generally applicable to petroleum operations, ${ }^{41}$ except for those specifically named and excluded in this article of the Model Contract. ${ }^{42}$ For purposes of the foreign tax credit for certain IOC Contractors, it is desirable both to: (a) reaffirm the Contractor's liability to generally applicable laws of the host government which impose taxes on or measured by income or profits; and (b) confirm that the Competent Authority's share of petroleum from the Contract Area, taken pursuant to the applicable provisions of a Petroleum Agreement, includes an amount equal in value to all of the income and profit taxes due by the Contractor under its Petroleum Agreement. ${ }^{43}$

Also, a provision will appear in this article to the effect that prior to the commencement of commercial production, the Competent Authority and the contractor will agree on a lifting procedure for their respective production shares on a regular basis. Some Model Contracts will detail the essential provisions of such a lifting procedure while others will go further and attach a pro forma lifting agreement as an appendix.

As earlier mentioned in Section II.K above, in host governments which are known or expected to be particularly gas-prone, both the Petroleum Law and the Model Contract will contain a separate article providing for special incentives and priorities for contractor to develop such natural gas. Supra note 20.

"It is interesting to note that, after several years of uncertainty under an essentially unworkable licensing and taxing systems, the Russian Federation, by a Presidential Decree of December 24, 1993, instituted the option of a PSC, under which the production sharing arrangement negotiated between the parties will be in lieu of all taxes otherwise payable on petroleum operations.

Those exclusions will normally be taxes on the income of subcontractors, income tax on the contractor's employees and those of its subcontractors, duties and taxes on locally purchased goods and commercial services provided by public authorities, and taxes on tobacco and alcohol. on behalf of the contractor which provides it with official receipts as evidence. 
7. PSC

A Simplified Example of the PSC Methodology

Calculation on a "Contractor's Tax Paid" Basis:

Assume:

1. Cost Oil agreed to be 30 percent of Gross Production; and

2. Profit Oil will be split on a "tax paid/after tax" basis after deduction of Cost Oil, as follows:

Production Level (Tranche) $\quad$ Percentage Share

$\begin{array}{lll}\text { BOPD } & \text { State } & \text { Contractor } \\ 0-50,000 & 65 & 35 \\ 50,001-100,000 & 67.5 & 32.5 \\ 100,001-150,000 & 70 & 30 \\ 150,000-200,000 & 72.5 & 27.5 \\ 200,001 \text { and up } & 75 & 25\end{array}$

3. Thus, actual production sharing between State and Contractor will be:
A. Profit Oil (after tax)
State
Contractor
(i) $0-50,000$
$(.65 \times 50,000) \quad 32,500$
$(.35 \times 50,000)$
17,500
(ii) $50,000-100,000 \quad(.675 \times 50,000) 33,750$
$(.70 \times 50,000)$
16,250
(iii) $100,000-150,000(.70 \times 50,000) \quad 35,000$
$(.30 \times 50,000)$
15,000
(iv) $150,000-200,000(.725 \times 7,500) \quad 5,438$
TOTALS
$(.275 \times 7,500)$
$\underline{\underline{106,688}}$
$\underline{2,062}$
$\underline{\underline{50,812}}$
B. Cost Oil
$(.30 \times 250,000)$
75,000

\section{H. FEeS AND BONUSES}

Consistent with requirements in the Regulations, this article will set out the times of payment and the amounts of any land rentals or contract administration fees, signature bonus, declaration of commercial discovery bonus, and initial and additional production bonuses (set at incremental, sustained production levels). Each of these may be bid on and negotiated in the Petroleum Agreement. 


\section{PROTECTION OF THE ENVIRONMENT}

This principle complements the Contractor's general obligation under the Petroleum Law to carry out petroleum operations in accordance with good international oilfield practice. An up-to-date Model Contract will now require the Contractor to take all necessary steps to:

(a) ensure that petroleum operations avoid or, if unavoidable, minimize ecological damage or destruction;

(b) control the flow and prevent the escape or the avoidable waste of petroleum produced in the Contract Area;

(c) prevent damage or waste to petroleum-bearing strata; and

(d) prevent damage to land, fresh water supplies/aquifers, trees, crops, other plants, marine or animal life, buildings, or other structures.

If the Contractor fails to comply with any of the above requirements and pollution results, the Model Contract will require it, on an emergency basis, to control, clean up, and repair all such damage to the maximum extent feasible by using the best technology available for the purpose. If such pollution results from the Contractor's negligence, the established practice is to deny it the right to include the costs of such remedial procedures in its cost recoverable expenses under the Petroleum Agreement. In addition, the Model Contract will require the Contractor, at the termination of the Petroleum Agreement, to take all steps to ensure restoration of the environment where petroleum operations were carried out. ${ }^{44}$

\section{J. SUPPLY OF DOMESTIC MARKET; EMERGENCY REQUISITION}

Reaffirming the premise that the State owns all of its petroleum resources, subject to the Contractor's rights to an agreed portion thereof under a Petroleum Agreement, the Model Contract should provide both for the Competent Authority's right to require the Contractor to sell some portion of its production share to meet internal domestic demand, and in case of grave national emergency, war, or the imminent expectation of war, requisition all or part of petroleum production from the Contract Area while concurrently requiring Contractor to maximize petroleum production. This will be qualified in the former by requiring the Competent Authority to provide adequate advance notice to the Contractor ${ }^{45}$ of both required quantities of petroleum and duration of supply. Such an approach recognizes the Contractor's external long-term commitments to sell or utilize its production share. Both of the above-noted rights may be qualified by the Competent Authority's obligation to pay the Contractor for purchased or requisitioned petroleum at approval, an outline scheme for restoration of the operating environment. 
the international price calculated pursuant to the applicable provisions in the Petroleum Agreement.

\section{K. Training of Host Government Personnel}

If the State chooses to allocate the responsibilities of both the contract administration of the Petroleum Agreement and technical interface thereunder to its own NOC, it is best to require in the Petroleum Agreement that the Contractor shall train NOC personnel in all aspects of petroleum operations in a planned, systematic, and phased manner. Such training will be at the Contractor's expense, subject to allowable cost recovery under the Petroleum Agreement.

\section{Other Standard Provisions}

While the degree of detail and emphasis will vary considerably from one Model Contract or Petroleum Agreement to another, a complete Model Contract will always include articles addressing the following:

(a) Valuation of petroleum;

(b) Title to assets and data;

(c) Payment and currency;

(d) Accounts, financial reporting, and audits;

(e) Records, inspection, and confidentiality;

(f) Force Majeure;

(g) Termination and events of default;

(h) Applicable law and stabilization;

(i) International arbitration and expert determination;

(j) Notices; and

(k) Effectiveness and amendment.

Additional standard appendices to a Model Contract will include a map and a description of the Contract Area, as well as a standard form of Accounting Procedure. The latter incorporates principles and procedures of accounting generally in use in the international petroleum sector. 


\section{International Practice}

\section{A. The Value of Knowing International Practice}

One of the most common questions that arises in advising governments regarding the preparation of Petroleum Laws, Regulations, and Model Contracts concerns the applicable usual practice of the oil and gas industry. Host governments want to know that the fiscal, economic, and business terms applicable to their petroleum regime are competitive with those offered in other jurisdictions. They also want to know that the benefits and opportunities provided by IOCs under the regimes established in other jurisdictions (for example, the training and employment of local personnel) are also provided to the host government. In negotiating the terms of petroleum contracts, IOCs and host governments also face these questions. If an international practice exists, it can be a negotiating tool encouraging IOCs and host governments to support a particular position.

Thus the challenge is to determine what the international practice is with respect to a particular issue. This is difficult, because there are so many oil and gas jurisdictions, many of which have different fiscal regimes applicable to different activities in that jurisdiction. Also, the terms of particular Petroleum Agreements may be separately negotiated between the host governments and different IOCs, resulting in an array of different provisions.

\section{B. International Practice Review}

Despite the difficulty in determining international practice, the Association of International Petroleum Negotiators has undertaken a project with such a goal in mind. However, the results of a project are not yet available.

One of the authors has performed international practice reviews of a large number of the issues that arise in Petroleum Agreements. This work has been done based on a database of more than eighty international oil and gas agreements from over sixty countries. ${ }^{46}$ The database includes Model Contracts from many host governments and a selection of actual Petroleum Agreements entered into between host governments and IOCs in many jurisdictions around the world.

These international practice reviews provide interesting insights into some of the important issues that form part of a petroleum regime. The reviews comprise three parts: a memorandum analyzing the results, a table summarizing the provisions of the individual Model Contracts and Petroleum Agreements reviewed, and excerpts of the relevant provisions from the Model Contracts and Petroleum Agreements. Some of the issues reviewed are described below, including an analysis of the results of an international

This database of international oil and gas agreements can be found in the PetroCash ${ }^{\circ}$ Database and Model, Version 2000.01, copyright Van Meurs \& Associates Ltd., Barrows, Inc., and Pricewaterhouse Coopers. The PetroCash ${ }^{\circ}$ Database and Model provides a comprehensive database of the legal, economic, and tax aspects of the world upstream petroleum industry as well as a model to carry out economic analysis on any petroleum fiscal regime in the world. The international practice reviews described in this article are soon to be added to the PetroCash ${ }^{\circ}$ Database and Model. 
practice review. However, because the scope and quantity of this material is so large, its inclusion in this article is not possible.

\section{Selected International Practice Review Issues}

A summary table describing the provisions of the agreements in the PetroCash ${ }^{\circ}$ database regarding the issues of governing law and arbitration is attached as an annex to this article. Also attached is a copy of the excerpt of the relevant provisions of three of the eighty agreements reviewed. These are provided as an example of a portion of the content of a full international practice review. All of the other issues discussed below (and the many issues which are the subject of other international practice reviews) have similar summary tables and excerpts.

\section{(a) GOVERNING LAW}

An issue of interest to lawyers is that of the law chosen to govern the Petroleum Agreement. It seems obvious that most agreements would choose the local law as that applicable for the Petroleum Agreement. The PetroCash' database proves this presumption, as virtually all of the agreements adopt local law.

However, in many situations, the agreements are applicable to jurisdictions where some of the principles of commerce are not addressed by the law. This is especially true as it relates to common principles of oil and gas law. For these reasons, it is not uncommon to see that international oil and gas agreements also state that principles of international law shall apply to the contract. This is most common with respect to the application of international treaties, the terms of which are often expressly adopted by the provisions of the governing law clause. In the case of countries that are members of the European Union ("EU"), EU principles are adopted. In some cases international principles are adopted only if the local law does not address an issue, or if the international principle is consistent with local law. Occasionally there are references to the application of principles of law from jurisdictions where the exploitation of resources is common.

On occasion the principles of law of a specific foreign jurisdiction are referred to in the Petroleum Agreement. English law, New York law, Dutch law, and German law are all referred to in agreements in the PetroCash ${ }^{\circ}$ database. An agreement from Azerbaijan contains a statement that while Azeri and English law do not contain common principles, Alberta law is to apply.

The PetroCash ${ }^{\circ}$ database contains the Model Contracts which have been prepared by host governments for use in their jurisdiction, as well as certain Petroleum Agreements that have been negotiated and executed by IOCs. The agreements signed by IOCs tend to contain provisions which favour the interests of IOCs. For example, most Model Contracts adopt local law without reference to international principles. In the Petroleum Agreements signed by IOCs, it is more common that the issues of the uncertainty of local law are addressed through some reference to international principles. 


\section{(b) ARBITRATION}

Almost every agreement in the PetroCash ${ }^{\circ}$ database contains an arbitration provision, and virtually all adopt principles of international arbitration. The international principles are generally those of the United Nations Commission on International Trade Law ("UNCITRAL"), ICSID, or the International Chamber of Commerce ("ICC"), but occasionally others are referred to. The agreements commonly require that arbitrations occur in a neutral jurisdiction, such as Geneva or London.

\section{(c) MANAGEMENT AND CONTROL}

One of the most important issues in the operation of a Petroleum Agreement is the question of management and control. These provisions determine the scope of the IOC's freedom to decide how to conduct operations.

The majority of international oil and gas agreements provide for the creation of a committee comprised of representatives of the host government or NOC and the IOC. The most common structure provides for an equal number of representatives from the government or NOC and the IOC, but it is also common for representation to be determined by the relative participating interests of the parties. In most instances, decisions of the committee must either be unanimous or, where both parties have equal representation, are made by a majority vote. The role of the committee typically includes review and approval of work programs and budgets submitted by the operator or IOC which, together with the minimum work and expenditure obligations set out in the agreement, are the parameters for the operations to be conducted pursuant to the agreement.

In instances where the international oil and gas agreement does not provide for the establishment of a committee, the approval of the government or NOC is generally required for work programs and budgets. In a few instances, however, the IOC is allowed to develop and implement work programs and budgets without state approval, provided that they are consistent with the IOC's minimum work and expenditure obligations, applicable laws and regulations, and the terms of the agreement.

In most instances, the IOC is either appointed the initial operator or is given the authority to appoint an operator. Some agreements provide that the government or NOC and the IOC must agree upon an operator or, infrequently, that the NOC will act as operator.

Where the declaration of a commercial discovery is addressed, the IOC is typically empowered to make such a declaration. However, in some instances, the IOC's recommendation is subject to committee or government approval.

\section{(d) EMPLOYMENT AND TRAining OF Local Nationals}

Host governments seek to obtain particular benefits and advantages from the involvement in their country of IOCs. The employment and training of local nationals, the procurement of local goods and services, the transfer of technology and research, and 
development are some of the benefits that host governments desire. Thus it is not surprising to find that these matters are often addressed in the Petroleum Agreement.

The vast majority of international oil and gas agreements require the $\mathrm{OOC}$ to hire and train local nationals as part of its activities in the host country. Few agreements set a minimum number of employees that must be hired by the IOC, but it is common to require that the IOC give preference to local nationals who are suitably qualified for a position. A handful of agreements require the IOC to hire local nationals not only for the operations that are the subject of the agreement, but also for the IOC's other operations in the host country.

Approximately half of the agreements reviewed, required the IOC to make minimum training expenditures. Where minimum expenditures are established, they vary between $\$ 50,000$ and $\$ 400,000$ per year. It is not uncommon for these training expenditures to be required for local nationals who are not working on the operations that are the subject of the agreement.

\section{(e) PROCUREMENT OF LOCAL GOODS AND SERVICES}

The vast majority of international oil and gas agreements stipulate that the IOC give first preference to the purchase of local goods and services. The nature of the preference varies in each agreement, so a review of the excerpts is necessary to identify the specific wording of this preference. The provisions which appear to have been given the greatest thought in this area are careful to address the competitiveness of the price, quality, and time of delivery of the local goods and services.

The majority of the agreements grant to the IOC an exemption from import duties and customs applicable to goods and services imported for project operations. A number of these agreements limit the availability of this exemption to situations where local goods and services are not available at a competitive price.

TRANSFER OF TECHNOLOGY

Only 25 percent of the Petroleum Agreements contained in the PetroCash ${ }^{\circ}$ database explicitly require the IOC to transfer technology to the NOC or host government. One of the agreements expressly states that technology is not required to be transferred, and the balance are silent on the issue.

Those agreements which do include an obligation to transfer technology provide little guidance regarding how this obligation is to be performed. It is the writers' experience that it is difficult for host governments and NOCs to obtain effective transfer of technology. This is an area where international agreements could be improved.

RESEARCH AND DEVELOPMENT

Nine agreements in the PetroCash ${ }^{\circ}$ database contain provisions addressing research and development. Essentially, all of these contemplate contributions by the IOC to the host 
government that are applied to research and development matters of some kind. The amount of the fees and how they are calculated vary.

\section{(h) ENVIRONMENTAL LIABILITY}

Many international Petroleum Agreements contain provisions dealing specifically with environmental protection. Some of these agreements also deal specifically with the issue of liability for environmental damage. The vast majority of international Petroleum Agreements provide that the IOC is responsible for any loss or damage caused by, or in the course of, the IOC's operations. As such, in virtually all cases, environmental damage caused in the course of oil and gas exploration and of development activities would be the responsibility of the IOC.

None of the Petroleum Agreements which were reviewed imposed liability on the IOC for pre-existing environmental damage. Some agreements provide for the performance of a baseline study to determine the condition of the exploration area prior to the commencement of exploration and development activities by the IOC.

\section{(i) MINIMUM WORK AND SECURITY}

The vast majority of international Petroleum Agreements set out either minimum work obligations to be performed by the IOC, minimum expenditures to be made by the IOC, or both. In those agreements that provide for both minimum work and expenditure limits, many specify that the IOC will be relieved from the requirement to meet the minimum expenditure if the minimum work has been performed for less than this amount. However, none relieve the IOC from its obligation to meet the minimum work requirement if it has made the required minimum expenditures. Some agreements specify that both minima must be met.

Most of the Petroleum Agreements reviewed provide that a bank guarantee or like instrument guaranteeing performance must be provided by the IOC. Typically, these guarantees may be called to the extent that the IOC does not fulfil its work or expenditure obligations within the specified time period. Some agreements make no provision for guarantees, but provide that the IOC must pay an amount representing any shortfall in the minimum work or expenditure requirements. A few agreements set out minimum commitments but do not deal specifically with remedies if these commitments are not met.

\section{(j) STABILITY}

Approximately 20 percent of the agreements in the PetroCash ${ }^{\circ}$ database contain provisions which provide some assurance to the IOC that at least some of the principles governing the activities of the IOC will not be amended. The variety of these provisions prevent the drawing of generalizationsabout the "usual" stability provisions. However, the stability provisions address matters such as the fiscal terms and provisions of the Petroleum Agreement, and the principles of local law (including in particular, taxation and royalty matters, as well as customs and duty matters). 
This review relates only to the Petroleum Agreements contained in the PetroCash ${ }^{\circ}$ database. Many countries have stability provisions adopted in their local laws, especially those relating to foreign investment.

\section{Conclusion}

While the foregoing discussion of the essential elements of legislative frameworks used to foster development of the potential indigenous petroleum resources of host countries is intended to be reasonably comprehensive, it is by no means exhaustive. Within each of the essential elements of the basic components of Petroleum Law, Regulations, and Model Contract(s), there is room for a myriad of variations and innovation, depending upon the degree of actual or perceived hydrocarbon endowment of the host government. This is the threshold determination which will dictate the choices to be made on specific elements, terms, allowances, and incentives, within the basic parameters of the legislative norms. Indeed, the international practices of host governments regarding petroleum industry arrangements tend to create a greater diversity of hybrid arrangements, rather than settling on one or two common structures. This trend is not likely to change in the near future for several reasons. First, more countries are open to investment by $10 \mathrm{Cs}{ }^{47}$ Second, the projects that host governments are inviting IOCs to pursue are increasingly becoming more unique ${ }^{48}$ Third, more attention and investment is being focused on gas projects. And finally, host governments and the petroleum industry are addressing the issue of fluctuating product prices. However, the best principles and structures of world petroleum legislation as described in this article will continue to work effectively for all types of oil and gas business arrangements, and therefore represent the best approach to fostering oil and gas development.

47 Kuwait and Saudi Arabia have recently indicated that they intend to invite participation by IOCs, reversing the general rule that the Middle East is not interested in IOC involvement.

4* Rehabilitation of abandoned fields (as in Venezuela) and operation of fields with existing production (as in Kuwait) are two examples of this. 
ANNEX A

\section{Comparison of PetroCash ${ }^{\circ}$ International Oil \& Gas Agreements: Applicable Law \& Arbitration Provisions}

This table summarizes the "Applicable Law" and "Arbitration" provisions of certain international oil and gas agreements in the PetroCash ${ }^{\circ}$ database.

"Model/Party" refers to whether the agreement summarized was a model agreement or a specific agreement with a company; if it is the latter, the name of the company is shown.

"Local Law" refers to whether the agreement adopted the laws of the jurisdiction in which the operations occur.

"International Principles" refers to whether the agreement adopts international principles of law that might apply to the agreement. Exactly which principles are adopted, and how they interrelate with local laws, can only be determined by reference to the agreement, but some attempt has been made to summarize them below. Where no comment is made, the agreement says that local law and international laws will apply.

"International Arbitration" refers to whether the agreement adopts international arbitration principles, and if so, which principles (UNCITRAL, ICSID, ICC or others). Where international arbitration is not adopted, the agreement either does not refer to arbitration, or applies local arbitration laws or principles. 


\begin{tabular}{|c|c|c|c|c|c|}
\hline$\overline{\text { COUNTRY }}$ & DATE & $\begin{array}{l}\text { MODELT } \\
\text { PARTY }\end{array}$ & $\begin{array}{c}\overline{\text { LOCAL }} \\
\text { LAW }\end{array}$ & $\begin{array}{l}\text { INTERNATIONAL } \\
\text { PRINCIPLES }\end{array}$ & $\begin{array}{l}\text { INTERNATIONAL } \\
\text { ARBITRATION }\end{array}$ \\
\hline Albania & 1998 & Model & $\overline{\overline{Y e s}}$ & $\overline{\text { Yes }}$ & UNCITRAL \\
\hline Angola & 1997 & Model & Yes & No & UNCITRAL \\
\hline Angola & 1991 & Model & Yes & No & UNCITRAL \\
\hline Azerbaijan & 1996 & Amoco & $\begin{array}{l}\text { Yes, and English law; } \\
\text { if no common } \\
\text { principles, Alberta law; } \\
\text { and pacta sunt } \\
\text { servanda }\end{array}$ & pacta sunt servanda & $\begin{array}{l}\text { As provided in Azeri } \\
\text { foreign investment law }\end{array}$ \\
\hline Bangladesh & & Model & Yes & No & UNCITRAL \\
\hline Bangladesh & 1994 & Caim Energy PLC & Yes & No & ICSID \\
\hline Bangladesh & 1993 & Model & Yes & No & ICSID \\
\hline Belize & 1995 & Model & & & local or international \\
\hline Bolivia & 1997 & Maxus & Yes & No & $\begin{array}{l}\text { local arbitration, but } \\
\text { international principles }\end{array}$ \\
\hline Brazil & 1998 & Model (Draft) & Yes & No & ICC \\
\hline Bulgaria & 1992 & Model & Yes & No & $\begin{array}{l}\text { unclear; arbitration in } \\
\text { Geneva }\end{array}$ \\
\hline Cambodia & 1991 & Japex & Yes & No & UNCITRAL \\
\hline Cambodia & 1992 & Model & Yes & No & UNCITRAL \\
\hline
\end{tabular}




\begin{tabular}{|c|c|c|c|c|c|}
\hline COUNTRY & $\overline{\overline{\text { DATE }}}$ & $\begin{array}{l}\text { MODEL/ } \\
\text { PARTY }\end{array}$ & $\begin{array}{c}\text { LOCAL } \\
\text { LAW }\end{array}$ & $\begin{array}{l}\text { INTERNATIONAL } \\
\text { PRINCIPLES }\end{array}$ & $\begin{array}{l}\text { INTERNATIONAL } \\
\text { ARBITRATION }\end{array}$ \\
\hline Cambodia & 1991 & $\begin{array}{l}\text { Premier Oil, Australasia } \\
\text { Oil, Santos Exploration, } \\
\text { Repsol }\end{array}$ & Yes & No & UNCITRAL \\
\hline Cameroon & 1995 & Model & $?$ & $?$ & ICSID \\
\hline Chile & 1996 & Cardinal Resources & Yes & international treaties & No \\
\hline China & 1995 & Model & Yes & $\begin{array}{l}\text { Yes, if Chinese } \\
\text { principles do not exist }\end{array}$ & UNCITRAL \\
\hline China & 1996 & Shell & Yes & $\begin{array}{l}\text { Yes, if Chinese } \\
\text { principles do not exist }\end{array}$ & UNCITRAL \\
\hline Columbia & 1998 & Arco & Yes & No & No \\
\hline Columbia & 1995 & Model & Yes & No & No \\
\hline Croatia & 1996 & Model & Yes & Yes & $\begin{array}{l}\text { London Court of } \\
\text { International Arbitration }\end{array}$ \\
\hline$\overline{\text { Cuba }}$ & 1993 & Model & Yes & No & $\begin{array}{l}\text { ICC (technical disputes } \\
\text { only) }\end{array}$ \\
\hline Denmark & 1994 & Model & Yes & Yes (EU principles) & No \\
\hline Ecuador & 1995 & Triton & Yes & No & No \\
\hline Egypt & 1998 & Model & Yes & No & No \\
\hline $\begin{array}{l}\text { Egypt (gas } \\
\text { sales } \\
\text { agreement) } \\
\end{array}$ & 1994 & $\begin{array}{l}\text { Egypt General } \\
\text { Petroleum Corp. }\end{array}$ & Yes & No & $\begin{array}{l}\text { unknown; refers to } \\
\text { other agreement }\end{array}$ \\
\hline
\end{tabular}




\begin{tabular}{|c|c|c|c|c|c|}
\hline COUNTRY & DATE & $\begin{array}{l}\text { MODEL/ } \\
\text { PARTY }\end{array}$ & $\begin{array}{c}\text { LOCAL } \\
\text { LAW }\end{array}$ & $\begin{array}{l}\text { INTERNATIONAL } \\
\text { PRINCIPLES }\end{array}$ & $\begin{array}{l}\text { INTERNATIONAL } \\
\text { ARBITRATION }\end{array}$ \\
\hline Egypt & 1994 & $\begin{array}{l}\text { Egypt General } \\
\text { Petroleum Corp. }\end{array}$ & $\overline{\bar{Y} \text { Yes }}$ & No & $\begin{array}{l}\text { Cairo International } \\
\text { Arbitration Centre; or } \\
\text { UNCITRAL }\end{array}$ \\
\hline $\begin{array}{l}\text { Equitorial } \\
\text { Guinea }\end{array}$ & 1992 & $\begin{array}{l}\text { Meridian International } \\
\text { Corp. }\end{array}$ & Yes & Yes & ICSID \\
\hline Eritrea & 1997 & Anadarko & Yes & No & UNCITRAL \\
\hline Ethiopia & 1994 & Afar Exploration & Yes & No & UNCITRAL \\
\hline Gabon & 1988 & Tenneco, Wintershall & Yes & No & ICC \\
\hline Ghana & 1995 & Model & Yes & Yes & $\begin{array}{l}\text { Arbitration Institute of } \\
\text { Stockholm Chamber of } \\
\text { Commerce; } \\
\text { UNCITRAL }\end{array}$ \\
\hline Guatemala & & Model & Yes & No & No \\
\hline Guyana & 1997 & Maxus & Yes & No & ICSID \\
\hline Hungary & 1994 & Model & Yes & No & unclear \\
\hline India & 1998 & ModeI & Yes & No & UNCITRAL \\
\hline India & 1995 & Shell & Yes & $\begin{array}{l}\text { Yes (where not } \\
\text { inconsistent with Indian } \\
\text { law) }\end{array}$ & UNCITRAL \\
\hline Indonesia & & Unocal & Yes & No & ICC \\
\hline
\end{tabular}




\begin{tabular}{|c|c|c|c|c|c|}
\hline COUNTRY & $\overline{\text { DATE }}$ & $\begin{array}{l}\text { MODELT } \\
\text { PARTY }\end{array}$ & $\begin{array}{l}\text { LOCAL } \\
\text { LAW }\end{array}$ & $\begin{array}{l}\text { INTERNATIONAL } \\
\text { PRINCIPLES }\end{array}$ & $\begin{array}{l}\text { INTERNATIONAL } \\
\text { ARBITRATION }\end{array}$ \\
\hline Kazakhstan & 1997 & Model & Yes & $\begin{array}{l}\text { Yes, for international } \\
\text { treaties }\end{array}$ & $\begin{array}{l}\text { ICSID, or UNCITRAL } \\
\text { if Contractor not from } \\
\text { an ICSID state }\end{array}$ \\
\hline Latvia & 1995 & $\overline{A m O c o,} \overline{\mathrm{OPAB}}$ & Yes & Yes, for EU principles & $\begin{array}{l}\text { London Court of } \\
\text { Arbitration; ICC }\end{array}$ \\
\hline Libya & 1989 & Model & Yes & No & $\mathrm{ICC}$ \\
\hline Malaysia & & Model & Yes & No & No \\
\hline Malta & 1997 & Model & Yes & No & UNCITRAL \\
\hline Morocco & 1999 & Model & Yes & No & No \\
\hline Morocco & 1994 & Model & Yes & No & ICSID \\
\hline Myanmar & & Model & Yes & $\begin{array}{l}\text { Yes, where local law } \\
\text { does not exist }\end{array}$ & No \\
\hline Niger & 1992 & Hunt Oil & Yes & $\begin{array}{l}\text { Yes, where local law } \\
\text { does not exist; } \\
\text { principles in petroleum } \\
\text { resource countries } \\
\text { apply }\end{array}$ & ICSID \\
\hline Nigeria & 1993 & Model & Yes & No & ICC \\
\hline Oman & 1992 & Model & $\begin{array}{l}\text { No; "accepted } \\
\text { international principles" } \\
\text { apply }\end{array}$ & Yes & ICC \\
\hline
\end{tabular}




\begin{tabular}{|c|c|c|c|c|c|}
\hline COUUNTRY & $\overline{\text { DATE }}$ & $\begin{array}{l}\text { MODEL/ } \\
\text { PARTY }\end{array}$ & $\begin{array}{l}\text { LOCAL } \\
\text { LAW }\end{array}$ & $\begin{array}{l}\text { INTERNATIONAL } \\
\text { PRINCIPLES }\end{array}$ & $\begin{array}{l}\text { INTERNATIONAL } \\
\text { ARBITRATION }\end{array}$ \\
\hline Oman & 1996 & Triton & $\begin{array}{l}\text { Unclear; "accepted } \\
\text { international principles" } \\
\text { apply to interpretation } \\
\text { of agreement when } \\
\text { arbitrated; and } \\
\text { Government of Oman } \\
\text { agrees to relieve Triton } \\
\text { from loss when local } \\
\text { laws are inconsistent } \\
\text { with agreement }\end{array}$ & Yes & ICSID \\
\hline Pakistan & & Model & Yes & $\overline{\text { No }}$ & ICSID \\
\hline$\overline{\text { Peru }}$ & 1996 & Anadarko & Yes & No & ICC \\
\hline Romania & 1996 & Model & Yes & No & ICC \\
\hline Senegal & 1995 & Pecten, EDC & $\overline{\text { Yes }}$ & No & $\mathrm{ICC}$ \\
\hline South Africa & 1994 & Model & Yes & No & No \\
\hline
\end{tabular}




\begin{tabular}{|c|c|c|c|c|c|}
\hline COUNTRY & $\overline{\text { DATE }}$ & $\begin{array}{l}\text { MODEL/ } \\
\text { PARTY }\end{array}$ & $\begin{array}{c}\text { LOCAL } \\
\text { LAW }\end{array}$ & $\begin{array}{l}\text { INTERNATIONAL } \\
\text { PRINCIPLES }\end{array}$ & $\begin{array}{l}\text { INTERNATIONAL } \\
\text { ARBITRATION }\end{array}$ \\
\hline$\longdiv { \text { Syria } }$ & 1997 & Shell, Deminex & $\begin{array}{l}\text { Yes, except where } \\
\text { inconsistent with the } \\
\text { agreement; when } \\
\text { arbitrating a dispute, } \\
\text { interpret in accordance } \\
\text { with Syrian, Dutch, } \\
\text { English and German } \\
\text { law, or where } \\
\text { inconsistent, in } \\
\text { accordance with } \\
\text { accepted international } \\
\text { principles }\end{array}$ & $\overline{\text { Yes }}$ & UNCITRAL \\
\hline Tanzania & 1990 & Texaco & Yes & No & $\begin{array}{l}\text { ICC; ICSID if Tanzania } \\
\text { becomes a party }\end{array}$ \\
\hline $\begin{array}{l}\text { Trinidad \& } \\
\text { Tobago }\end{array}$ & 1996 & Model & Yes & No & UNCITRAL \\
\hline Tunisia & 1994 & Pluspetrol & $\begin{array}{l}\text { Yes (labour and social } \\
\text { welfare laws) }\end{array}$ & No & $?$ \\
\hline
\end{tabular}




\begin{tabular}{|l|l|l|l|l|l||}
\hline COUNTRY & DATE & \multicolumn{1}{|c|}{$\begin{array}{c}\text { MODEL/ } \\
\text { PARTY }\end{array}$} & \multicolumn{1}{|c|}{$\begin{array}{c}\text { LOCAL } \\
\text { LAW }\end{array}$} & $\begin{array}{l}\text { INTERNATIONAL } \\
\text { PRINCIPLES }\end{array}$ & $\begin{array}{c}\text { INTERNATIONAL } \\
\text { ARBITRATION }\end{array}$ \\
\hline \hline Turkmenistan & 1997 & Model & Yes & $\begin{array}{l}\text { Yes, principles of } \\
\text { international law and } \\
\text { decisions of } \\
\text { international tribunals } \\
\text { and treaties to which } \\
\text { Turkmenistan is a party }\end{array}$ & UNCITRAL \\
\hline Turkmenistan & 1996 & Petronas & Yes & Yes & $?$ \\
\hline Turkmenistan & 1997 & Model & Yes & Yes & UNCITRAL \\
\hline Uganda & 1993 & Model & Yes & Yes & ICSID \\
\hline Venezuela & 1997 & Union Texas, Preusag & Yes & $\begin{array}{l}\text { Yes; international } \\
\text { treaties regarding } \\
\text { protection of foreign } \\
\text { investment }\end{array}$ & ICC \\
\hline Venezuela & 1996 & Conoco & & $\begin{array}{l}\text { Yes; international } \\
\text { treaties regarding } \\
\text { protection of foreign } \\
\text { investment }\end{array}$ & ICC \\
\hline
\end{tabular}




\title{
ANNEX B
}

\section{Comparison of PetroCash ${ }^{\circ}$ International Oil \& Gas Agreements: Applicable Law \& Arbitration Provisions}

\author{
ALBANIA \\ 1998 Model Production Sharing Contract For Exploration \\ And Production Of Petroleum Onshore Albania
}

Article 23

Governing Law

23.1 The Parties agree that the Laws of Albania are applicable with due recognition of internationally accepted principles of law.

23.2 NPA acknowledges that CONTRACTOR has entered in this Contract in reliance on the laws, rules and regulations of Albania as they exist on the Effective Date of this Contract, and NPA hereby confirms that all rights granted to CONTRACTOR hereunder are in conformity with such laws, rules and regulations.

23.3 It is hereby agreed that if the Laws of Albania, including but not limited to tax laws and foreign exchange regulations, were subsequent to the signing of this Contract, to be changed in such a way as to diminish CONTRACTOR's rights and benefits or expand CONTRACTOR's obligations hereunder, NPA shall be bound to readjust the Contract so as to restore CONTRACTOR's rights benefits and obligations as existing on the Effective Date.

23.4 In the event that any change to the laws, rules or regulations of Albania occurs subsequently to the Effective date hereof which restricts, divests or limits any rights or benefits accruing to CONTRACTOR's or which increases CONTRACTOR's obligations under this Contract or under any laws, rules or regulations of Albania as in existence on the Effective Date hereof, CONTRACTOR may, at any time thereafter, so notify NPA in writing.

Within thirty (30) days from receipt of such notice, NPA and CONTRACTOR shall meet to negotiate in good faith and agree upon the modifications which need to be made to the terms of this Contract to restore CONTRACTOR's economic rights and benefits pursuant to Article 23.3. In the event that the Parties are unable to agree within ninety (90) days after the CONTRACTOR's notice to NPA either Party may refer the matter or matters in dispute for arbitration under Article 24.

The arbitrators in such event shall be empowered to determine whether a material change to the CONTRACTOR's rights, benefits or obligations has occurred and the modifications, if any necessary to the Contract to restore CONTRACTOR's economic rights and benefits to a level equivalent to what they would have been had such a change not occurred. The arbitrators' determination shall be final and binding and shall become part of this 
Contract. The Council of Ministers shall issue a decision whereby the determination of the arbitrators becomes effective pursuant to the terms of this Contract.

\section{Article 24 \\ Arbitration}

24.1 Any dispute, controversy, claim or difference of opinion including any purported termination under Article 27, arising out of or relating to this Contract or the breach, termination or validity thereof, or to the Petroleum Operations carried out hereunder, shall be finally and conclusively settled by arbitration in accordance with the UNCITRAL Arbitration Rules ("Rules").

24.2 With respect to the foregoing, the appointing authority under the Rules shall be the President of the Court of International Arbitration of the International Chamber of Commerce in Paris, France.

24.3 The number of arbitrators shall be three. The Party instituting the arbitration shall appoint one arbitrator and the Party, responding shall appoint another arbitrator, and upon failure of such responding Party to so appoint an arbitrator within thirty (30) days the Party instituting the arbitration may request the appointing authority to appoint such second arbitrator in accordance with the Rules. The two (2) arbitrators thus appointed shall choose the third arbitrator who will act as the presiding arbitrator of the tribunal.

24.4 If, within thirty (30) days of appointment of the second arbitrator to be appointed, the two (2) appointed arbitrators cannot agree upon the third arbitrator either Party may request the appointing authority to appoint the third arbitrator.

24.5 The arbitration shall take place in Zurich, Switzerland. The language to be used in the arbitration proceedings shall be English. The Parties expressly waive any right to appeal an arbitral award to any court whatsoever, and the arbitral award shall be final and binding upon the Parties.

24.6 The arbitral award shall contain the reasons upon which the award is based and an award of costs.

24.7 The right to arbitrate under this Article 24 shall survive the termination of this Contract.

24.8 NPA expressly waives any right to claim sovereign immunity in connection will any proceeding instituted pursuant to this Article 24, any proceeding - to compel enforcement of this Article 24, or any proceeding to enforce any award made by arbitration under this Article 24.

24.9 Judgment on the award rendered may be entered in any Court having jurisdiction or application may be made to such Court for a Judicial acceptance of the award and an order of enforcement, as the case may be. 
24.10 Any matter in dispute between NPA and CONTRACTOR which in terms of this Contract is to be referred to an Expert, shall be referred for determination by a sole expert. The Expert shall be given terms of reference which shall be mutually agreed between the Parties. The Expert shall be appointed by agreement between NPA and CONTRACTOR. If NPA and CONTRACTOR fail to appoint the expert within thirty (30) days after agreement on the terms of reference has been reached, either Party may apply to the International Chamber of Commerce Centre for Technical Expertise, Paris, France, for appointment of an expert in accordance with its Rules. The Expert shall make his determination in accordance with the provisions contained herein based on the best evidence available to him. Representatives of NPA and CONTRACTOR shall have the right to consult with the Expert and furnish him with data and information, provided the Expert may impose reasonable limitations on this right. Any such data and information has to be submitted to the other Party to the dispute at the same time. The Expert shall be free to evaluate the extent to which any data, information or other evidence is substantiated or pertinent. The Expert's fees and expenses, and the costs associated with an appointment, if any, made by the International Chamber of Commerce Centre for Technical Expertise, shall be borne equally by NPA and CONTRACTOR. The Expert's determination shall be final and binding upon the Parties, subject to any manifest error in his determination. 


\section{ANGOLA}

\section{Model Production Sharing agreement Between Sociedade Nacional De Comnbustiveis de Angola - Unidade Economica Estatal (Sonangol, U.E.E.) And Contractor}

34. "Law" means the legislation in force in the Republic of Angola.

\section{Article 42 \\ Arbitration}

1. Any disputes, differences, or claims arising out of this Agreement or relating thereto, or relating to the breach, termination, or invalidation of the same, which it has not been possible to resolve amicably shall be finally and exclusively settled by arbitration, in accordance with the UNCITRAL Rules of Arbitration of 1976 as existing on the Effective Date.

2. The number of arbitrators shall be three (3). One will be appointed by Sonangol and 1 (one) by the CONTRACTOR GROUP. The third arbitrator will be appointed jointly by SONANGOL and the CONTRACTOR GROUP. If one of the arbitrators is not appointed within thirty days upon SONANGOL's or the CONTRACTOR GROUP's notice to, the other, asking for said appointment, then such arbitrator shall be appointed by the President of the International Chamber of Commerce of Paris.

3. The arbitration tribunal shall decide according to the Angolan substantive Law.

4. According to the Law in force the arbitration tribunal shall be set up in Luanda and the language of arbitration shall be Portuguese.

5. The Parties agree that this arbitration clause is an explicit waiver of immunity against validity and enforcement of the award or any judgment thereon and that the award or judgment shall be final, binding and shall be enforceable against any Litigant in any court having jurisdiction in accordance with its laws.

Article 44

Applicable Law

This Agreement shall be governed by and construed in accordance with the Law.

\section{ANGOLA}

1991 Model Production Sharing Agreement For Deep Water Blocks Between SONANGOL \& International Companies 


\section{AZERBAIJAN}

Amoco Group Agreement Dated 14 December 1996

On The Exploration, Development \& Production Sharing

For Prospective Structures Ashrafi, Dan Ulduzu \& Area Adjacent

In The Azerbaijan Sector Of The Caspian Sea

\section{ARTICLE 22}

\section{APPLICABLE LAW, ECONOMIC STABILISATION AND ARBITRATION}

\section{1}

\section{Applicable Law}

This Agreement shall be governed and interpreted in accordance with principles of law common to the law of the Azerbaijan Republic and English law, and to the extent that no common principles exist in relation to any matter then in accordance with the principles of the common law of Alberta, Canada (except for laws regarding conflicts of laws). This Agreement shall also be subject to the international legal principle of pacta sunt servanda (agreements must be observed). Upon approval by the Parliament of the Azerbaijan Republic of this Agreement, this Agreement shall constitute a law of the Azerbaijan Republic and shall take precedence over any other current or future law, decree or administrative order (or part thereof) of the Azerbaijan Republic which is inconsistent with or conflicts with this Agreement except as specifically otherwise provided in this Agreement.

\subsection{Economic Stabilisation}

The rights and interests accruing to Contractor (or its assignees) under this Agreement and its Sub-contractors under this Agreement shall not be amended, modified or reduced without the prior consent of Contractor. In the event that any Governmental Authority invokes any present or future law, treaty, intergovernmental agreement, decree or administrative order which contravenes the provisions of this Agreement or adversely or positively affects the rights or interests of Contractor hereunder, including, but not limited to, any changes in tax legislation, regulations, or administrative practice, or jurisdictional changes pertaining to the Contract Area, the terms of this Agreement shall be adjusted to re-establish the economic equilibrium of the Parties, and if the rights or interests of Contractor have been adversely affected, then SOCAR shall indemnify the Contractor (and its assignees) for any disbenefit, deterioration in economic circumstances, loss or damages that ensue therefrom. SOCAR shall within the full limits of its authority use its reasonable lawful endeavours to ensure that the appropriate Governmental Authorities will take appropriate measures to resolve promptly in accordance with the foregoing principles any conflict or anomaly between any such treaty, intergovernmental agreement, law, decree or administrative order and this Agreement.

\subsection{Arbitration}

(a) Except for any matter to be referred to an expert pursuant to Articles 12.1(b) or 12.3(b), or except as otherwise expressly set forth herein, in the event of a 
dispute arising between SOCAR and any or all of the Contractor Parties (including matters which have been unresolved at the Steering Committee), the disputing Parties shall meet in an attempt to resolve the dispute to their mutual satisfaction by reference to the terms of this Agreement. If satisfactory mutual agreement is not achieved within thirty (30) days after receipt by a Party of notice of such dispute, such dispute shall be settled in accordance with the Arbitration Procedure and the applicable law provisions of Article 22.1.

(b) Nothing in this Agreement shall limit the rights of the Contractor Parties pursuant to Articles 11 through 15 of the Law on Protection of Foreign Investment dated 15 January 1992, which rights shall apply in addition to any other rights Contractor may have under this Agreement notwithstanding any other law, both current and future, in the Azerbaijan Republic. If any of Contractor's rights, interests or property are expropriated, nationalised or otherwise taken by reason of any act or failure of act of any Governmental Authority, then the arbitrators shall apply the principle of indemnification (including prompt, full and effective compensation in Dollars) at the full market value, on the basis of an ongoing concern utilising the discounted cash flow method, assuming a willing buyer and seller in a non-hostile environment, and disregarding the unfavourable circumstances under which or following which Contractor shall be deprived of its rights, interest (including its interest in undeveloped reserves) or property. The arbitrators shall select an investment bank of good international reputation for purpose of appraising the full market value of said rights, interest (including its interest in undeveloped reserves) or property of Contractor.

(c) The rights and obligations under this Section 22.3 shall survive the termination of this Agreement. 